\title{
Effect of Composition and Processing Conditions on Selected Properties of Potato-Based Pellets and Microwave-Expanded Snacks Supplemented with Fresh Beetroot Pulp
}

\author{
Katarzyna Lisiecka ${ }^{1}$, Agnieszka Wójtowicz ${ }^{1 *}$ ๑) Agnieszka Sujak ${ }^{2}$ () \\ ${ }^{1}$ Department of Thermal Technology and Food Process Engineering, \\ University of Life Sciences in Lublin, Gtęboka 31, 20-612 Lublin, Poland \\ ${ }^{2}$ Department of Biosystems Engineering, \\ University of Life Sciences in Poznań, Wojska Polskiego 50, 60-637 Poznań, Poland
}

Key words: extrusion-cooking, snack pellets, beetroot, microwave expansion, chemical composition, molecular structure

The aim of this study was to evaluate the influence of the addition of fresh beetroot pulp in amounts from 2.5 to $30.0 \mathrm{~g} / 100 \mathrm{~g}$, as well as variable screw speeds $(60,80,100 \mathrm{rpm})$ on the chemical composition, water absorption, water solubility index, density, expansion rate, and texture of potatobased pellets and expanded snacks. Their protein and starch structure was analyzed using the Fourier-transformed infrared (FTIR) spectroscopy. The snack pellets were made at a moisture content of $33 \mathrm{~g} / 100 \mathrm{~g}$ of blends using a single-screw extruder equipped with a plasticizing unit having a length-to-diameter ratio (L/D) of 18 . Processing temperature ranged from 65 to $105^{\circ} \mathrm{C}$. The ready-to-eat snacks were expanded using microwave treatment $(750 \mathrm{~W}, 40 \mathrm{~s})$. Fresh vegetable pulp addition raised the protein content. The extrusion-cooking caused an increase in the content of insoluble dietary fiber and water absorption index of the pellets. In contrast, the microwave treatment reduced values of these parameters in expanded products and decreased the insoluble dietary fiber content of the expanded snacks. The addition of fresh beetroot pulp diminished the expansion ability and increased the content of $\beta$-sheet proteins. Additionally, an increase in the content of $\beta$-turn and $\beta$-sheet protein fractions was observed at the expense of random coil structure. This indicates that the protein structure underwent some form of ordering as the molecular interactions of the proteins intensified. The highest fraction of $\beta$-structures and the smallest content of random coil were observed when $80 \mathrm{rpm}$ was applied during processing. It seems to be the most efficient screw speed in processing fresh beetroot pulp-supplemented snack pellets. Application of a fresh beetroot pulp as an additive in microwave expanded snacks made it possible to obtain products with an increased amount of fiber and a reduced fat content as an attractive and healthy alternative to deep-fried snacks.

\section{INTRODUCTION}

One of the most popular natural polysaccharides used in snack manufacture is starch, being a carbohydrate made of amylose and amylopectin fractions. Its botanical origin determines the main changes in starch processing and quality of final products [Sakač et al., 2020]. Starches of various biological origin differ in the degree of polymerization, the amylose to amylopectin ratio, and molecular organization of the crystalline regions of granules [Błaszczak et al., 2005]. The knowledge of physicochemical, functional, and structural properties of starch, such as gelatinization, retrogradation, solubility, swelling power, water retention capacity, rheological behavior, and pasting properties are very useful in snack production [Sanchez-González et al., 2019].

The Fourier-transformed infrared (FTIR) spectroscopy is a universal analytical technique that can be applied to analyze structural changes in processed materials [Kowalczuk
\& Pitucha, 2019]. However, it has not yet been employed in the study of the properties of potato-based pellets or snack foods.

Products processed by means of extrusion-cooking are a significant element of the diet of people all over the world. Generally, extruded snacks are the most attractive products for children and young consumers. Therefore, very often, the snacks are enriched with extra ingredients, such as fruits, vegetables, herbs or other plant additives [Bhat et al., 2019; Lisiecka \& Wójtowicz, 2019]. Potato-based snack pellets are the most popular snack items on the market, appearing in different shapes and flavors.

Extruded snack pellets need to be expanded in order to obtained ready-to-eat (RTE) snacks. Among the typical expansion methods applied are deep oil frying, hot air puffing, or microwave heating. Microwave treatment, as an alternative method of pellet expansion, reduces fat content in RTE products as compared to conventional expansion by frying in deep

\footnotetext{
* Corresponding Author:

Tel.: + (48) 814456127

E-mail: agnieszka.wojtowicz@up.lublin.pl (Prof. A. Wójtowicz)
}

Submitted: 25 March 2021 
oil [Lisiecka \& Wójtowicz, 2021]. It is also an easy and inexpensive process to execute either on an industrial scale or at household conditions [Ruiz-Armenta et al., 2019].

Beetroot is a very popular vegetable in Poland, mostly consumed as cooked or baked or used as a soup ingredient. Dry beetroot and beetroot extracts are added to many food products as natural colorants, while other beneficial effects of beetroots are attributable to their antiviral, antidiabetic, cytotoxic, and allelopathic properties [Mikołajczyk-Bator et al., 2016]. Fresh beetroot pulp is valued for its natural purple color and the high content of valuable nutritional components, not degraded by the drying process. Fresh beetroots are available on the market all year round due to the use of controlled atmosphere storage, which is an effective way to ensure an appropriate quality and microbiological safety. When used at home, beetroots are cleaned and cooked or baked without any microbiological risk. Moreover, because the extrusioncooking is a high-temperature process, the processing by its means can be used as a method of thermal sterilization. As previously presented [Lisiecka \& Wójtowicz, 2020], the use of fresh vegetables can significantly reduce the water volume needed in the technological process and the energy needed for the drying process. Thus, the use of fresh vegetables as additives to this type of indirectly expanded snacks has many advantages. After drying, the pellets have a moisture content below $11 \mathrm{~g} / 100 \mathrm{~g}$, which makes them stable and safe for storage.

This study aimed to examine the changes that take place in RTE snacks after extrusion of pellets at various screw speeds and following microwave expansion, with regard to the effect of replacing potato starch with increasing amounts of vegetable pulp. The novelty of this study lies in the use of fresh beetroot pulp rather than dry powdered vegetables to produce pellets, as in the case of most research performed [Bhat et al., 2019; Ruiz-Armenta et al., 2019].

\section{MATERIALS AND METHODS}

\section{Raw materials}

Potato flakes, grits, and starch were donated by Pol-Foods Sp. z o. o. (Prostki, Poland). Fresh beetroot was bought at a local market. The vegetables were washed with tap water, drained with paper towels, and ground with a laboratory knife mill LMN-100 TestChem (Radlin, Poland) with a sieve with opens below $400 \mu \mathrm{m}$. Next, after mixing with potato components, the blends were sifted again before moistening and processing.

\section{Extrusion-cooking of snack pellets}

The control blend composition was as follows: $25 \mathrm{~g} / 100 \mathrm{~g}$ of potato flakes, $25 \mathrm{~g} / 100 \mathrm{~g}$ of potato grits, and $50 \mathrm{~g} / 100 \mathrm{~g}$ of potato starch. Other samples were fortified with the fresh beetroot pulp at a range from 2.5 to $30.0 \mathrm{~g} / 100 \mathrm{~g}$ by replacing the respective amount of potato starch. The moisture content was assessed through employing a standard reference American Association of Cereal Chemists 44-15.02 air-oven method $\left(130^{\circ} \mathrm{C}, 1 \mathrm{~h}\right)$ [AACC, 1995] both for dry components and for beetroot pulp after grinding. Calculation of water amount added was done in accordance to the previous paper [Lisiecka \& Wójtowicz, 2020] to reach the moisture content of blends at $33 \mathrm{~g} / 100 \mathrm{~g}$ (sum of water content in all components by weight). Firstly, dry components were mixed, then fresh pulp was added, mixed together, and the proper amount of water was added to each blend. During hydration, the components were mixed continuously for about $15 \mathrm{~min}$.

A single screw extruder type TS-45 (ZMCh Metalchem, Gliwice, Poland) with a length-to-diameter ratio at $\mathrm{L} / \mathrm{D}=18$ of the plasticizing unit, with a screw of 3:1 compression ratio, and with an intensive glycol cooling installation of the last barrel section was employed to produce snack pellets. During processing, variable screw speeds were applied: 60, 80, and $100 \mathrm{rpm}$. The temperature profile during processing was set at $80^{\circ} \mathrm{C}$ in the dozing section, $105^{\circ} \mathrm{C}$ in the cooking section, and $65^{\circ} \mathrm{C}$ in the cooling section.

Snack pellets were shaped as dough strips using a $30 \times 0.4 \mathrm{~mm}$ flat forming die and cut to approx. $30 \times 30 \mathrm{~mm}$ pieces. The pellets were subsequently dried in a laboratory shelf dryer at $40^{\circ} \mathrm{C}$ for $10 \mathrm{~h}$ to their final moisture content of $11 \mathrm{~g} / 100 \mathrm{~g}$. The extrudates produced were kept in tightly closed foil packages before further testing.

\section{Microwave expansion}

Snack pellets were expanded by a treatment in a microwave oven (AVM-914/WH Philips/Whirlpool, Sweden). The optimum expansion conditions, i.e., microwave power of $750 \mathrm{~W}$ and exposure time of $40 \mathrm{~s}$, were selected experimentally as treatment parameters. After expansion, the snacks were cooled to ambient temperature and stored in plastic bags before subsequent testing. Samples of both pellets and snacks were ground (if needed) before tests in a laboratory grinder (LMN-100, TestChem, Poland) to a particle size below $300 \mu \mathrm{m}$.

\section{Water absorption index (WAI) and water solubility index (WSI) of pellets and RTE snacks}

Water absorption index (WAI) and water solubility index (WSI) were determined according to the methods described by Lisiecka et al. [2021] in triplicate. The ratio of the gel weight to the dry sample weight was defined as WAI. The ratio of the weight of dry solids in the supernatant to the weight of the dry sample was derived as WSI.

\section{Bulk density (BD) and volumetric expansion index (VEI) of snacks}

The bulk density (BD) was specified as the weight of the sample divided by the occupied volume of the cylinder [Han et al., 2018]. Volumetric expansion index (VEI) was calculated as the ratio of the density of pellets and snacks after expansion. The measurements were performed in 5 replications.

\section{Texture analysis of microwave-expanded snacks}

The texture analysis was employed to determine selected properties of snacks, including hardness $(\mathrm{H})$, crispness $(\mathrm{CR})$, and fracturability (FR). It was conducted using a Kramer shear cell by a compression test on single extrudates. During the measurement, the head test speed was $100 \mathrm{~mm} / \mathrm{min}$. Texture measurements were performed in 5 replications [Alvarez et al., 2020; Shah et al., 2017]. 


\section{FTIR analysis and data manipulation}

FTIR spectroscopy was applied to check the protein and starch structures in the examined pellets and in the RTE microwave-expanded snacks. A Nicolet iS50 FTIR spectrometer (Thermo Scientific, Waltham, MA, USA) equipped with a diamond attenuated total reflectance attachment (GladiATR attachment, PIKE Technologies, Madison, WI, USA) was employed to collect spectra between 4000 and $400 \mathrm{~cm}^{-1}$ at a $4 \mathrm{~cm}^{-1}$ resolution. Before the FTIR measurements had been taken, ground samples were dried under a vacuum for $3 \mathrm{~h}$. To obtain an optimal signal-to-noise ratio, 128 scans were collected. Each spectra was baseline-corrected using OMNIC software (version 8.2, Thermo Fischer Scientific, Waltham, MA, USA). The analyzed spectra were averaged over three registered spectra series. Spectral analyses were carried out by employing GRAMS AI Spectral Notebase (Thermo Fisher Scientific) [Pytlak et al., 2020].

In order to separate the bands representing certain protein structures in the amide I region and to allow identification of the protein secondary structural constitutes, the second derivative of the amide I band was calculated by applying 5-point, second-degree polynomial function. Following this, the derivative spectra were smoothed via 11-point second-degree polynomial Savitsky-Golay function according to Seabourn et al. [2008] and Susi \& Byler [1983]. All amide I bands were baseline corrected and area normalized.

To estimate the fraction of different types of secondary structure, the amide I band $\left(1590-1720 \mathrm{~cm}^{-1}\right)$ was deconvoluted with Gaussian curves using Grams 32 AI (version 9) software (Galactic, Salem, NH, USA) as indicated by the second derivative peak position identification. The quality of the band deconvolution was indicated by the following parameters: $\mathrm{R}^{2}>0.99$, solution converged, and $\chi^{2}<0.001$. The composition of secondary protein structure participating in the amide I band was expressed as a percentage of the area of the fitted region denoted as a relative area of components centered at specific wavenumbers [Bock \& Damodaran, 2013]. The secondary structure assignment was based on absorption wavenumbers as described previously [Fetouhi et al., 2019].

Amide I secondary structures: $\alpha$-helix $\left(1649-1659 \mathrm{~cm}^{-1}\right)$, $\beta$-sheet $\left(1620-1644 \mathrm{~cm}^{-1}\right), \beta$-turn $\left(1660-1688 \mathrm{~cm}^{-1}\right)$, and random coils (1510-1619 $\left.\mathrm{cm}^{-1}\right)$ were assigned. Crystalline and amorphous fractions of starch were studied by estimating ratio $\mathrm{R}$ equal to the proportion of the intensities I $\left(1047 \mathrm{~cm}^{-1}\right)$ / I $\left(1022 \mathrm{~cm}^{-1}\right)$ [Smits et al., 1998].

\section{Chemical composition of pellets and RTE snacks}

Based on the results of physical, textural, and structural characteristics, the optimum products were selected to perform chemical components analysis. Protein (AACC 46-10), fat (AACC 30-10), and ash (AACC 08-01) contents were determined in triplicate [AACC, 1995]. Contents of soluble and insoluble dietary fiber and its total content were duplicate-tested by applying the Association of Official Agricultural Chemists International 993.21 method [AOAC, 2000]. The final results were expressed on a wet basis.

\section{Statistical analysis}

The obtained results were subjected to statistical analyses using Statistica 13.3 software (StatSoft, Tulsa, OK, USA).
Homogeneous groups were determined by ANOVA by using Tukey post-hoc test at $\alpha=0.05$. Moreover, principal component analysis (PCA) was performed for the tested characteristics of pellets and microwave-expanded snacks processed at $80 \mathrm{rpm}$ as the optimum screw speed, by Statistica software. Additionally, during the analysis of the main PCA components, a correlation matrix was created between the examined features and expressed as Persons' coefficients.

\section{RESULTS AND DISCUSSION}

\section{Physical properties of pellets and snacks}

To prepare the expanded samples, the optimum microwave conditions were checked experimentally by several trials to avoid burning the pellets if the frequency or time were too intensive or too low, and if not the whole pellet surface was expanded uniformly. In our study, the microwave power of $750 \mathrm{~W}$ and the treatment time of $40 \mathrm{~s}$ were selected based on preliminary trials as the best conditions to avoid both burning the samples or uncomplete expansion. Chen et al. [2014] found that the drying time was significantly reduced with the microwave power increase when vacuum microwave drying was used to prepare fish crisps. But they also pointed out that the higher power density would easily lead to the burning of fish samples and to the deterioration of their quality. The microwave power over $4 \mathrm{~W} / \mathrm{g}$ led to the cooking of samples, resulting in a significant deterioration of their quality, therefore they selected this microwave power for further study. In turn, Ruiz-Armenta et al. [2019] manufactured expanded snack products using a conventional microwave oven with a power of $1,450 \mathrm{~W}$ and a frequency of $2,450 \mathrm{MHz}$ by selecting microwave heating for $20 \mathrm{~s}$ after testing different heating times $(16,18,20,22,24,26$, and 28 s). Given the above findings, it can be concluded that the application of a higher microwave power allows reducing heating time to obtain properly expanded products. However, since the availability of microwave ovens with a power over $1000 \mathrm{~W}$ is limited, the conditions selected in our study make it possible to obtain expanded fat-free snacks at household conditions.

Several physical properties were evaluated for the extruded pellets and microwave-expanded snacks. The water absorption index indicates the ability of the product components to absorb and hold water [Lourenço et al., 2016] and measures the amount of gel which is formed by starch, protein, and fiber after swelling in the presence of extra water [Kaur et al., 2015]. During the extrusion-cooking, gelatinization of starch and protein denaturation occur under appropriate conditions. Gelatinized starch absorbs more water than it does in its native state. However, the presence of proteins or fibers in the extrudate composition may increase or decrease the WAI due to their conformational and structural changes affecting the hydrophilic/hydrophobic balance [Lourenço et al., 2016].

According to our research, the WAI of the control potato blend before extrusion was $3.71 \pm 0.04 \mathrm{~g} / \mathrm{g}$, whereas its WSI was $1.28 \pm 0.47 \%$. The WAI and WSI values of fresh beetroot pulp-supplemented pellets and microwave-expanded snacks are presented in Table 1. The WAI and the WSI of all extruded samples were higher in comparison to the control potato 
TABLE 1. Water absorption index (WAI) and water solubility index (WSI) of extruded pellets and microwave-expanded snacks supplemented with fresh beetroot pulp.

\begin{tabular}{|c|c|c|c|c|c|}
\hline \multirow{2}{*}{$\begin{array}{l}\text { Content of beetroot } \\
\text { pulp }(\mathrm{g} / 100 \mathrm{~g})\end{array}$} & \multirow{2}{*}{$\begin{array}{l}\text { Screw speed } \\
\quad(\mathrm{rpm})\end{array}$} & \multicolumn{2}{|c|}{ WAI (g/g) } & \multicolumn{2}{|c|}{ WSI (\%) } \\
\hline & & $\mathrm{P}$ & S & $\mathrm{P}$ & S \\
\hline \multirow{3}{*}{0} & 60 & $4.62 \pm 0.14^{c}$ & $5.28 \pm 0.03^{\mathrm{a}}$ & $5.12 \pm 0.78^{b}$ & $7.05 \pm 1.57^{\mathrm{a}}$ \\
\hline & 80 & $6.83 \pm 0.69^{\mathrm{ab}}$ & $5.35 \pm 0.20^{\mathrm{a}}$ & $1.42 \pm 0.53^{\mathrm{c}}$ & $5.75 \pm 1.23^{\mathrm{ab}}$ \\
\hline & 100 & $7.26 \pm 0.20^{\mathrm{a}}$ & $5.19 \pm 0.01^{\mathrm{a}}$ & $3.12 \pm 0.53^{\mathrm{bc}}$ & $2.57 \pm 0.12^{\mathrm{de}}$ \\
\hline \multirow{3}{*}{2.5} & 60 & $4.59 \pm 0.06^{c}$ & $4.58 \pm 0.17^{\mathrm{cd}}$ & $3.70 \pm 0.65^{\mathrm{b}}$ & $4.24 \pm 0.58^{\mathrm{bc}}$ \\
\hline & 80 & $6.20 \pm 0.09^{b}$ & $5.00 \pm 0.08^{\mathrm{bc}}$ & $2.57 \pm 0.94^{\mathrm{bc}}$ & $3.91 \pm 0.19^{\mathrm{cd}}$ \\
\hline & 100 & $6.00 \pm 0.11^{\mathrm{bc}}$ & $5.20 \pm 0.03^{\mathrm{a}}$ & $2.75 \pm 0.18^{\mathrm{bc}}$ & $2.27 \pm 0.30^{\text {de }}$ \\
\hline \multirow{3}{*}{5.0} & 60 & $6.21 \pm 0.02^{b}$ & $4.73 \pm 0.03^{\mathrm{cd}}$ & $2.46 \pm 0.07^{\mathrm{bc}}$ & $3.96 \pm 0.58^{\mathrm{cd}}$ \\
\hline & 80 & $6.77 \pm 0.04^{\mathrm{ab}}$ & $4.95 \pm 0.15^{\mathrm{bc}}$ & $4.48 \pm 1.47^{b}$ & $4.48 \pm 0.65^{\mathrm{bc}}$ \\
\hline & 100 & $7.32 \pm 0.08^{\mathrm{a}}$ & $5.02 \pm 0.05^{\mathrm{ab}}$ & $6.49 \pm 2.93^{\mathrm{ab}}$ & $2.85 \pm 0.81^{\text {de }}$ \\
\hline \multirow{3}{*}{7.5} & 60 & $7.10 \pm 0.11^{\mathrm{ab}}$ & $4.77 \pm 0.26^{\mathrm{cd}}$ & $7.08 \pm 2.85^{\mathrm{ab}}$ & $4.20 \pm 0.19^{\mathrm{cd}}$ \\
\hline & 80 & $7.53 \pm 0.14^{\mathrm{a}}$ & $4.57 \pm 0.18^{\mathrm{cd}}$ & $2.04 \pm 1.55^{\mathrm{c}}$ & $3.19 \pm 0.48^{\mathrm{cd}}$ \\
\hline & 100 & $5.96 \pm 0.10^{\mathrm{bc}}$ & $5.38 \pm 0.03^{\mathrm{a}}$ & $5.02 \pm 1.29^{b}$ & $3.34 \pm 0.51^{\mathrm{cd}}$ \\
\hline \multirow{3}{*}{10.0} & 60 & $6.70 \pm 0.08^{\mathrm{ab}}$ & $4.38 \pm 0.07^{\mathrm{cd}}$ & $6.98 \pm 3.37^{\mathrm{ab}}$ & $2.85 \pm 0.58^{\mathrm{de}}$ \\
\hline & 80 & $6.83 \pm 0.07^{\mathrm{ab}}$ & $4.67 \pm 0.08^{\mathrm{cd}}$ & $8.63 \pm 2.93^{\mathrm{a}}$ & $4.18 \pm 0.06^{\mathrm{cd}}$ \\
\hline & 100 & $6.94 \pm 0.03^{\mathrm{ab}}$ & $4.48 \pm 0.08^{\mathrm{cd}}$ & $4.74 \pm 0.85^{\mathrm{b}}$ & $3.55 \pm 1.61^{\mathrm{cd}}$ \\
\hline \multirow{3}{*}{20.0} & 60 & $5.69 \pm 0.05^{\mathrm{bc}}$ & $3.73 \pm 0.04^{e}$ & $6.21 \pm 0.31^{\mathrm{ab}}$ & $2.84 \pm 0.36^{\mathrm{de}}$ \\
\hline & 80 & $6.01 \pm 0.14^{\mathrm{bc}}$ & $4.75 \pm 0.13^{\mathrm{cd}}$ & $5.79 \pm 0.62^{\mathrm{ab}}$ & $4.35 \pm 1.46^{\mathrm{bc}}$ \\
\hline & 100 & $6.11 \pm 0.12^{\mathrm{bc}}$ & $4.98 \pm 0.01^{\mathrm{bc}}$ & $3.03 \pm 0.51^{\mathrm{b}}$ & $2.14 \pm 0.12^{\mathrm{e}}$ \\
\hline \multirow{3}{*}{30.0} & 60 & $5.92 \pm 0.07^{\mathrm{bc}}$ & $4.60 \pm 0.07^{\mathrm{cd}}$ & $3.88 \pm 1.81^{\mathrm{b}}$ & $5.92 \pm 0.37^{\mathrm{ab}}$ \\
\hline & 80 & $7.16 \pm 0.60^{\mathrm{a}}$ & $4.51 \pm 0.14^{\mathrm{cd}}$ & $6.27 \pm 1.10^{\mathrm{ab}}$ & $4.77 \pm 0.05^{\mathrm{bc}}$ \\
\hline & 100 & $7.03 \pm 0.23^{\mathrm{ab}}$ & $4.67 \pm 0.13^{\mathrm{cd}}$ & $4.03 \pm 0.27^{b}$ & $5.04 \pm 0.50^{\mathrm{bc}}$ \\
\hline
\end{tabular}

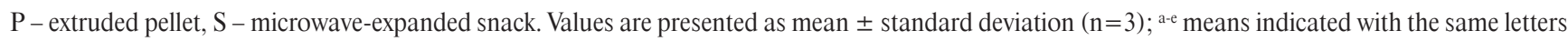
in columns do not differ significantly at $\alpha=0.05$.

blend before extrusion. In contrast, microwave expansion decreased the WAI of all samples compared to the corresponding half-products (pellets), except for the control sample produced at $60 \mathrm{rpm}$. This could be due to the reactions between proteins, amylose, and amylopectin, leading to WAI reduction [Sharma et al., 2015].

The WSI is a very important parameter of extrusion-cooking intensity, and makes it possible to predict the material behavior during further processing [Rashid et al., 2015]. In our research, the maximum WSI was determined at $8.63 \%$ for the pellet with beetroot pulp at $10.0 \mathrm{~g} / 100 \mathrm{~g}$ processed at $80 \mathrm{rpm}$ and at $7.05 \%$ for the control potato snacks produced at the lowest screw speed. The minimum WSI was obtained for the control pellets extruded at $80 \mathrm{rpm}(1.42 \%)$ and for the microwave-expanded snacks containing $20.0 \mathrm{~g} / 100 \mathrm{~g}$ of fresh beetroot pulp processed at $100 \mathrm{rpm}$ (2.14\%).

Researchers who experimented with expanding corn starch-based pellets supplemented with naranjita and milk powder observed an increase in WSI after extrusion and after microwave treatment [Ruiz-Armenta et al., 2019].
They concluded that this was linked to the loss of the semicrystalline form of native starch granules after processing.

The bulk density (BD), volumetric expansion index (VEI), and texture parameters of the microwave-expanded snacks are presented in Table 2. The highest values of $\mathrm{BD}$ were recorded at each additive level when the highest screw speed was applied during pellet processing, except for the $20 \mathrm{~g} / 100 \mathrm{~g}$ additive level; however, the results obtained for this level did not differ significantly from others. The highest $\mathrm{BD}$ values were determined at $76.03 \mathrm{~kg} / \mathrm{m}^{3}, 76.80 \mathrm{~kg} / \mathrm{m}^{3}$ and $76.36 \mathrm{~kg} / \mathrm{m}^{3}$ for the snacks without additive and for the snack with 5.0 and 7.5 $\mathrm{g} / 100 \mathrm{~g}$ additive content extruded at $100 \mathrm{rpm}$, respectively. Nevertheless, the differences between the tested samples were in most cases statistically insignificant $(\mathrm{p} \geq 0.05)$. The lowest bulk density was determined at $57.90 \mathrm{~kg} / \mathrm{m}^{3}$ for the snacks with $2.5 \mathrm{~g} / 100 \mathrm{~g}$ of beetroot pulp extruded at $60 \mathrm{rpm}$. These snacks also featured a high value of the volumetric expansion index, but their hardness was surprisingly high. Moreover, the highest VEI value was recorded for the samples without the vegetable additive extruded at $100 \mathrm{rpm}$ (6.17). The increasing 
TABLE 2. Selected physical and textural features of microwave-expanded snacks supplemented with fresh beetroot pulp.

\begin{tabular}{|c|c|c|c|c|c|c|}
\hline $\begin{array}{l}\text { Content of beetroot } \\
\text { pulp }(\mathrm{g} / 100 \mathrm{~g})\end{array}$ & $\begin{array}{c}\text { Screw speed } \\
(\mathrm{rpm})\end{array}$ & $\begin{array}{c}\mathrm{BD} \\
\left(\mathrm{kg} / \mathrm{m}^{3}\right)\end{array}$ & $\begin{array}{c}\text { VEI } \\
(-)\end{array}$ & $\begin{array}{c}\mathrm{H} \\
(\mathrm{N}) \\
\end{array}$ & $\begin{array}{l}\mathrm{CR} \\
(\mathrm{N}) \\
\end{array}$ & $\begin{array}{l}\text { FR } \\
(\mathrm{N}) \\
\end{array}$ \\
\hline \multirow{3}{*}{0} & 60 & $71.45 \pm 5.15^{\mathrm{abc}}$ & $4.77 \pm 0.45^{\text {bcde }}$ & $170.40 \pm 15.96^{\mathrm{abc}}$ & $10.47 \pm 1.50^{c}$ & $26.07 \pm 4.96^{c}$ \\
\hline & 80 & $70.52 \pm 7.76^{\mathrm{abc}}$ & $5.10 \pm 0.61^{\mathrm{abc}}$ & $158.00 \pm 14.06^{\mathrm{cbd}}$ & $34.97 \pm 5.62^{\mathrm{a}}$ & $37.58 \pm 6.76^{\mathrm{a}}$ \\
\hline & 100 & $76.03 \pm 3.73^{b}$ & $6.17 \pm 0.66^{\mathrm{a}}$ & $195.40 \pm 19.17^{\mathrm{a}}$ & $29.52 \pm 5.45^{\mathrm{ab}}$ & $36.30 \pm 6.12^{\mathrm{ab}}$ \\
\hline \multirow{3}{*}{2.5} & 60 & $57.90 \pm 2.66^{\mathrm{e}}$ & $5.34 \pm 0.14^{\mathrm{ab}}$ & $183.00 \pm 4.97^{\mathrm{ab}}$ & $23.57 \pm 1.91^{\mathrm{abc}}$ & $27.63 \pm 3.95^{\mathrm{abc}}$ \\
\hline & 80 & $67.84 \pm 1.81^{\mathrm{abcd}}$ & $5.04 \pm 0.54^{\mathrm{abcd}}$ & $145.33 \pm 7.41^{\text {cbde }}$ & $16.73 \pm 3.83^{\mathrm{bc}}$ & $27.63 \pm 7.11^{\mathrm{abc}}$ \\
\hline & 100 & $74.53 \pm 2.76^{\mathrm{abc}}$ & $4.87 \pm 0.37^{\text {bcde }}$ & $160.00 \pm 6.98^{\mathrm{abcd}}$ & $14.58 \pm 3.27^{c}$ & $26.00 \pm 5.00^{\mathrm{abc}}$ \\
\hline \multirow{3}{*}{5.0} & 60 & $63.40 \pm 1.67^{\mathrm{cd}}$ & $4.11 \pm 0.19^{\text {bcdef }}$ & $156.00 \pm 10.10^{\mathrm{cbd}}$ & $19.54 \pm 5.01^{\mathrm{bc}}$ & $26.40 \pm 5.37^{\mathrm{abc}}$ \\
\hline & 80 & $71.31 \pm 0.93^{\mathrm{abc}}$ & $4.16 \pm 0.22^{\mathrm{bcdef}}$ & $139.63 \pm 9.61^{\text {cdef }}$ & $14.48 \pm 3.21^{\mathrm{c}}$ & $19.56 \pm 2.11^{\mathrm{c}}$ \\
\hline & 100 & $76.80 \pm 3.99^{\mathrm{ab}}$ & $4.74 \pm 0.36^{\text {bcdef }}$ & $108.33 \pm 2.49^{\mathrm{ef}}$ & $19.40 \pm 4.43^{\mathrm{bc}}$ & $26.03 \pm 4.51^{\mathrm{abc}}$ \\
\hline \multirow{3}{*}{7.5} & 60 & $64.01 \pm 3.66^{\mathrm{acd}}$ & $4.34 \pm 0.60^{\text {bcdef }}$ & $111.07 \pm 11.48^{\mathrm{ef}}$ & $17.09 \pm 2.22^{\mathrm{bc}}$ & $19.17 \pm 2.90^{c}$ \\
\hline & 80 & $72.36 \pm 0.84^{\mathrm{abc}}$ & $4.63 \pm 0.11^{\text {bcdef }}$ & $102.57 \pm 5.12^{\mathrm{f}}$ & $18.73 \pm 1.50^{\mathrm{bc}}$ & $24.83 \pm 2.90^{\mathrm{abc}}$ \\
\hline & 100 & $76.36 \pm 3.15^{\mathrm{ab}}$ & $4.92 \pm 0.24^{\text {abcde }}$ & $130.87 \pm 3.78^{\text {def }}$ & $13.10 \pm 2.61^{\mathrm{c}}$ & $13.82 \pm 3.26^{c}$ \\
\hline \multirow{3}{*}{10.0} & 60 & $64.28 \pm 3.86^{\mathrm{acd}}$ & $3.85 \pm 0.21^{\text {cdef }}$ & $174.33 \pm 9.10^{\mathrm{abc}}$ & $16.85 \pm 5.05^{\mathrm{bc}}$ & $21.98 \pm 2.16^{\mathrm{abc}}$ \\
\hline & 80 & $63.09 \pm 2.04^{\mathrm{cd}}$ & $4.52 \pm 0.18^{\text {bcdef }}$ & $159.00 \pm 11.58^{\mathrm{cbd}}$ & $15.62 \pm 2.85^{\mathrm{bc}}$ & $23.11 \pm 5.67^{\mathrm{abc}}$ \\
\hline & 100 & $72.20 \pm 0.87^{\mathrm{abc}}$ & $4.54 \pm 0.21^{\text {bcdef }}$ & $161.33 \pm 14.52^{2 \mathrm{abcd}}$ & $21.22 \pm 5.82^{\mathrm{abc}}$ & $24.77 \pm 2.31^{\mathrm{abc}}$ \\
\hline \multirow{3}{*}{20.0} & 60 & $64.39 \pm 0.79^{\mathrm{acd}}$ & $3.64 \pm 0.22^{\mathrm{ef}}$ & $174.67 \pm 9.84^{\mathrm{abc}}$ & $24.00 \pm 4.46^{\mathrm{abc}}$ & $27.43 \pm 4.77^{\mathrm{abc}}$ \\
\hline & 80 & $64.68 \pm 0.69^{\mathrm{abcd}}$ & $4.29 \pm 0.25^{\text {bcdef }}$ & $169.33 \pm 9.88^{\mathrm{abcd}}$ & $19.40 \pm 2.76^{\mathrm{bc}}$ & $19.50 \pm 2.76^{c}$ \\
\hline & 100 & $61.89 \pm 0.59^{\mathrm{cd}}$ & $5.35 \pm 0.21^{\mathrm{ab}}$ & $173.33 \pm 5.31^{\mathrm{abc}}$ & $15.75 \pm 2.67^{\mathrm{bc}}$ & $21.74 \pm 3.75^{\mathrm{bc}}$ \\
\hline \multirow{3}{*}{30.0} & 60 & $64.60 \pm 1.65^{\mathrm{abcd}}$ & $3.79 \pm 0.22^{\mathrm{def}}$ & $107.93 \pm 10.82^{\mathrm{ef}}$ & $15.23 \pm 5.92^{c}$ & $15.77 \pm 5.60^{c}$ \\
\hline & 80 & $70.99 \pm 3.25^{\mathrm{abc}}$ & $3.47 \pm 0.10^{\mathrm{f}}$ & $169.67 \pm 4.99^{\mathrm{abcd}}$ & $18.70 \pm 5.02^{\mathrm{bc}}$ & $19.37 \pm 4.60^{c}$ \\
\hline & 100 & $72.52 \pm 4.18^{\mathrm{abc}}$ & $4.54 \pm 0.43^{\text {bcdef }}$ & $135.67 \pm 8.22^{\text {cdef }}$ & $18.80 \pm 6.79^{\mathrm{bc}}$ & $24.90 \pm 4.80^{\mathrm{abc}}$ \\
\hline
\end{tabular}

BD - bulk density; VEI - volumetric expansion index; H - hardness; CR - crispness; FR - fracturability. Values are presented as mean \pm standard deviation $(n=5)$; ${ }^{\text {-f }}$ means indicated with the same letters in columns do not differ significantly at $\alpha=0.05$.

amount of fresh vegetable pulp lowered the VEI values, but at the same time lowered the hardness of the expanded snacks with up to $10 \mathrm{~g} / 100 \mathrm{~g}$ of the additive; however, the differences were in most cases insignificant $(\mathrm{p} \geq 0.05)$. Further increasing the content of fresh beetroot pulp resulted in still low BD but lowered VEI, and after the microwave expansion the snacks supplemented with 10.0 and $20.0 \mathrm{~g} / 100 \mathrm{~g}$ became harder than the samples with 5.0 or $7.5 \mathrm{~g} / 100 \mathrm{~g}$ of beetroot pulp, probably due to the increased fiber content in RTE products. Expanded potato-based snacks should be characterized by low BD, suggesting good expansion after the final treatment, but the ultimate effect is directly connected with the expansion method used. Lisiecka \& Wójtowicz [2021] demonstrated low BD of oil-fried snacks that ranged from $38.3 \mathrm{~kg} / \mathrm{m}^{3}$ for the control snacks produced at $60 \mathrm{rpm}$ to $64.0 \mathrm{~kg} / \mathrm{m}^{3}$ for the fresh beetroot pulp-supplemented snacks. In most cases, BD of fried snacks was lower than of the microwave-expanded ones (Table 2) due to formation of an expanded internal structure with multiple empty pores inside snacks as influenced by steam evaporation during frying. Ruiz-Armenta et al. [2019] tested indirectly expanded corn starch-based snacks prepared by microwaves (1450 and $2450 \mathrm{~W}$ for $20 \mathrm{~s}$ ) and found that the expansion rate of RTE products ranged from 8.61 to 9.83 , and their density from 95.41 to $106.55 \mathrm{~kg} / \mathrm{m}^{3}$, which is higher than in our research. As reported by Lisiecka et al. [2021], after hot oil frying of extruded pellets supplemented with Allium genus vegetables, the bulk density of fried snacks varied from $38.3-56.2 \mathrm{~kg} / \mathrm{m}^{3}$ for the control potato snacks, while the highest $\mathrm{BD}$ reached $87.2 \mathrm{~kg} / \mathrm{m}^{3}$ if $20.0 \mathrm{~g} / 100 \mathrm{~g}$ of leek was used and $70.7 \mathrm{~kg} / \mathrm{m}^{3}$ if $7.5 \mathrm{~g} / 100 \mathrm{~g}$ of onion was added. When analyzing fried snacks made of composite flour prepared from barnyard millet, green gram, fried gram, and ajwain seeds, Krishnaraj et al. [2019] found that the water molecules were converted into steam during the quick heating and that oil was filling empty spaces, which could lead to much higher bulk density of the fried snacks compared to these treated with microwaves as low-fat products. Thus, several benefits can be found when expanding pellets with microwave heating, including both nutritional benefits because of the low energy value of the product as well as economic benefits for producers due its the low density.

The hardness of microwave-expanded snacks supplemented with fresh beetroot pulp ranged from $102.57 \mathrm{~N}$ to $195.40 \mathrm{~N}$ (for the snack with $7.5 \mathrm{~g} / 100 \mathrm{~g}$ vegetable pulp in the recipe processed at $80 \mathrm{rpm}$ and for the control sample extruded 
at the maximum rotational speed of the extruder screw, respectively). The snacks from the control sample extruded at $80 \mathrm{rpm}$ had the highest values of crispness and fracturability $(34.97 \mathrm{~N}$ and $37.58 \mathrm{~N}$ ), while the control snacks extruded at $60 \mathrm{rpm}$ featured the lowest values of crispness $(10.47 \mathrm{~N})$. Moreover, the lowest fracturability was determined at $13.82 \mathrm{~N}$ for the snacks with $7.5 \mathrm{~g} / 100 \mathrm{~g}$ fresh beetroot pulp when extruded at $100 \mathrm{rpm}$, but in most cases the results did not differ significantly $(\mathrm{p} \geq 0.05)$. The increasing level of beetroot pulp in snacks, as well as the variable screw speed, ambiguously affected their textural properties after microwaving, probably due to inhomogeneity in the pores inside the expanded snacks structure that resulted the inconclusive texture profile of RTE products. Nevertheless, the crispness and fracturability of the supplemented snacks expanded by microwaves were more similar than those of the control snacks.

\section{FTIR spectra of pellets and snacks}

Figures 1 and 2 show exemplary baseline-corrected and surface-normalized FTIR spectra of pellets (Figure 1a-c) and microwaved snacks (Figure 2a-c) registered over the wavelengths between 3900-450 $\mathrm{cm}^{-1}$. There are six clear groups of bands registered in the wavelength ranges between 3700-3000, 2950 $-2800,1750-1500,1500-1250$, and $1200-900 \mathrm{~cm}^{-1}$ and several peaks below $900 \mathrm{~cm}^{-1}$, respectively. The first group of bands contains the NH stretching vibration of amide A (3600$-3450 \mathrm{~cm}^{-1}$ ) overlapped with $\mathrm{OH}$ stretching vibration (bounded water; $\left.3550-3200 \mathrm{~cm}^{-1}\right)$. Another group represents the amide B (3000-2600 $\mathrm{cm}^{-1}$ ) bands overlapped with peaks representing stretching vibrations of $\mathrm{CH}_{2}$ and $\mathrm{CH}_{3}$ groups $\left(2950-2800 \mathrm{~cm}^{-1}\right)$.
The band between 1750 and $1500 \mathrm{~cm}^{-1}$ represents amide I and amide II bands centered at $1640 \mathrm{~cm}^{-1}$ (amide I) and $1540 \mathrm{~cm}^{-1}$ (amide II - conformationally sensitive) due to $\mathrm{CO}$ carbonyl stretch with a minor contribution from out-of-plane $\mathrm{CN}$ stretching vibration, as well as $\mathrm{NH}$ bonding and $\mathrm{CH}$ stretching of proteins, respectively. The band between $1350 \mathrm{~cm}^{-1}$ and $1200 \mathrm{~cm}^{-1}$, characteristic of amide III region, reveals $\mathrm{NH}$ in-plane bending coupled with $\mathrm{C}$-N-stretching and includes $\mathrm{CH}$ and $\mathrm{NH}$ deformation modes.

Furthermore, the spectral region of polysaccharides (1200-900 $\mathrm{cm}^{-1}$ ) is characteristic for backbone vibrations of $\mathrm{CO}, \mathrm{CN}$, and $\mathrm{CC}$ groups (stretching modes), while the peak at $994 \mathrm{~cm}^{-1}$ is sensitive to water content and starch conformation [van Soest et al., 1995]. Finally, the low intensity peaks in the spectral region below $900 \mathrm{~cm}^{-1}$ belong to $\mathrm{CH}$ out-of-plane bending $\left(900-675 \mathrm{~cm}^{-1}\right), \mathrm{OH}$ bending $\left(770-650 \mathrm{~cm}^{-1}\right)$, and to $\mathrm{NH}_{2}$ and $\mathrm{H}_{2}$ wagging vibrations $\left(900-660 \mathrm{~cm}^{-1}\right)$. The collective analysis showed an increasing proportion of water with the increasing fresh beetroot pulp content in relation to polysaccharides and proteins in the case of pellets and the opposite in the case of snacks. The analysis of the region between $2950-2800 \mathrm{~cm}^{-1}$ indicated a lower lipid content in snacks compared to pellets. No major differences were found related to different screw speeds.

\section{Analysis of the amide I region}

Processing variables dependence of the relative composition of protein secondary structures calculated on the basis of deconvolution of FTIR spectra in the amide I region are presented in Figure 3. Figure $3 \mathrm{a}$ and $3 \mathrm{~b}$ show the $\beta$-sheet

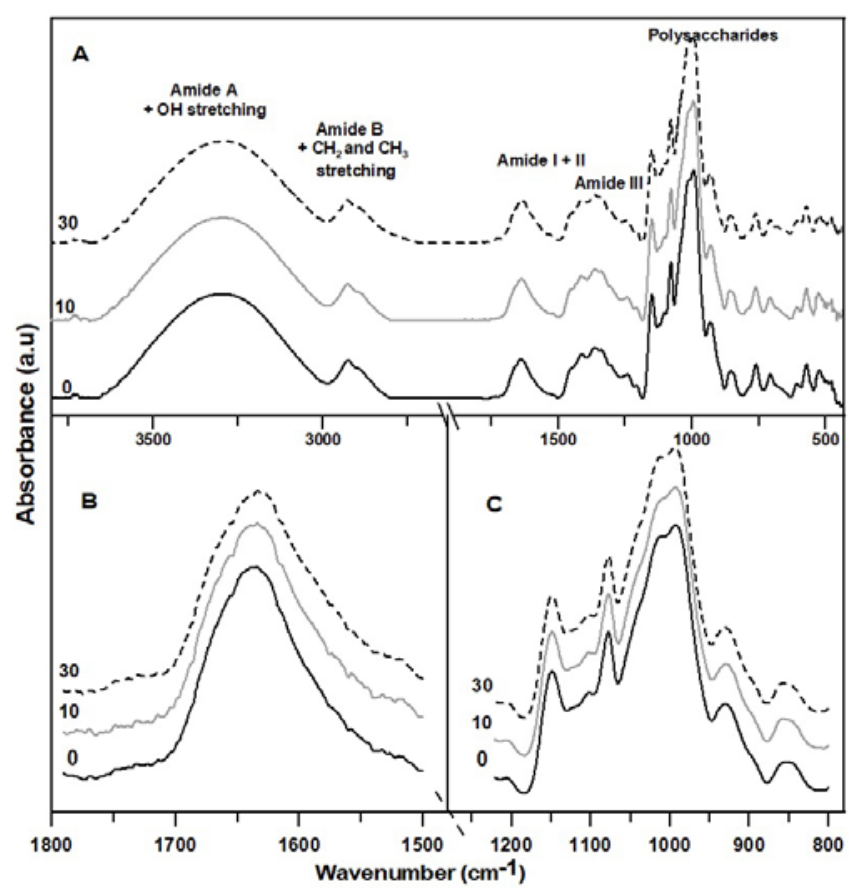

FIGURE 1. Baseline-corrected and surface-normalized FTIR spectra of pellets over the wavelengths $3900-450 \mathrm{~cm}^{-1}$ (a), 1750-1500 $\mathrm{cm}^{-1}$ (b), 1200 $-900 \mathrm{~cm}^{-1}$ (c). Black line: control potato pellets; Grey line: pellets with the addition of $10.0 \mathrm{~g} / 100 \mathrm{~g}$ fresh beetroot pulp; Dotted line: pellets with the addition of $30.0 \mathrm{~g} / 100 \mathrm{~g}$ fresh beetroot pulp.

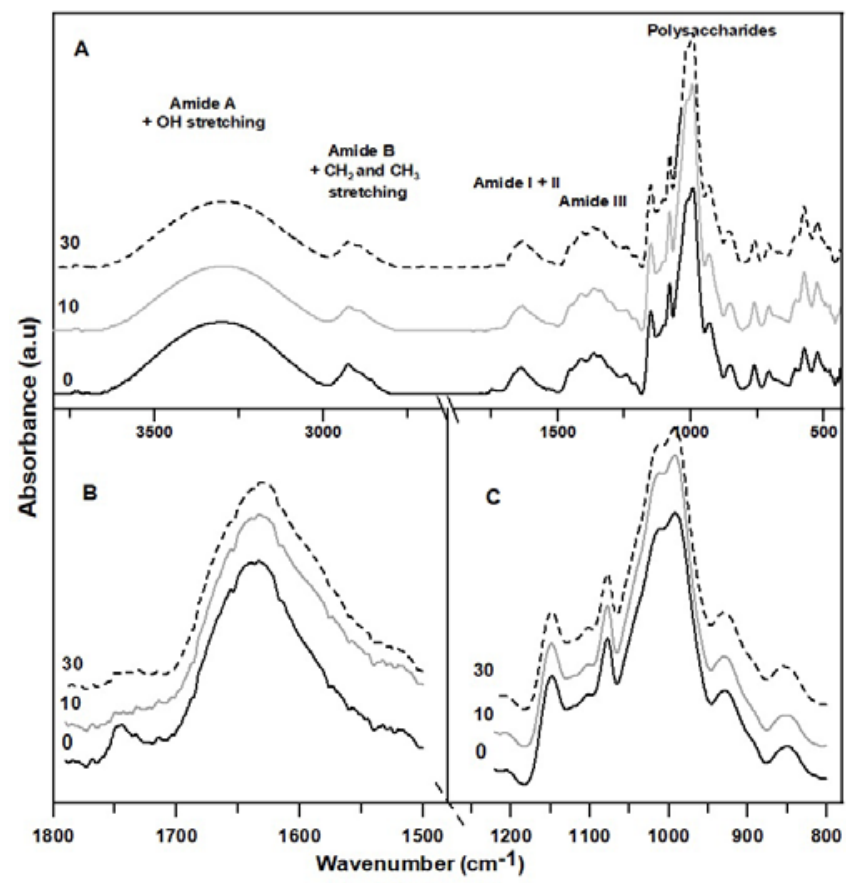

FIGURE 2. Baseline-corrected and surface-normalized FTIR spectra of microwave-expanded snacks over the wavelengths $3900-450 \mathrm{~cm}^{-1}$ (a), 1750$-1500 \mathrm{~cm}^{-1}$ (b), 1200-900 $\mathrm{cm}^{-1}$ (c). Black line: control potato pellets; Grey line: pellets with the addition of $10.0 \mathrm{~g} / 100 \mathrm{~g}$ fresh beetroot pulp; Dotted line: pellets with the addition of $30.0 \mathrm{~g} / 100 \mathrm{~g}$ fresh beetroot pulp. 
content of pellets and RTE snacks, respectively, while the $\beta$-turn content of the pellets and expanded snacks is presented in Figure $3 \mathrm{c}$ and $3 \mathrm{~d}$, respectively. In addition, the random coil content of the pellets and snacks evaluated by FTIR analysis is shown in Figure $3 e$ and 3f, respectively.

As shown by the analysis of protein structure by deconvolution of amide I band, $\beta$-sheet was the main protein structure in the control sample, in the dried beetroot pulp, as well as in the examined pellets and snacks. Protein fractions in the control sample (not subjected to the extrusion process) containing potato flakes, potato grits, and starch had $8 \pm 0.07 \%$ of $\beta$-turn, $20 \pm 0.18 \%$ of $\alpha$-helix, $55 \pm 0.50 \%$ of $\beta$-sheet, and $17 \pm 0.16 \%$ of random coil structures. In contrast, dried beetroot protein contained $8 \pm 0.06 \%$ of $\beta$-turn, no $\alpha$-helix, $90 \pm 0.63 \%$ of $\beta$-sheet, and $1.7 \pm 0.01 \%$ of random coil structures. No $\alpha$-helix structure was found in the samples regardless of screw rotation speed and additives - apart from the pellets containing $30.0 \mathrm{~g} / 100 \mathrm{~g}$ of fresh beetroot pulp processed at $60 \mathrm{rpm}$ where its content reached $13.6 \pm 0.01 \%$. This phenomenon can be attributable to the extrusion-cooking a)

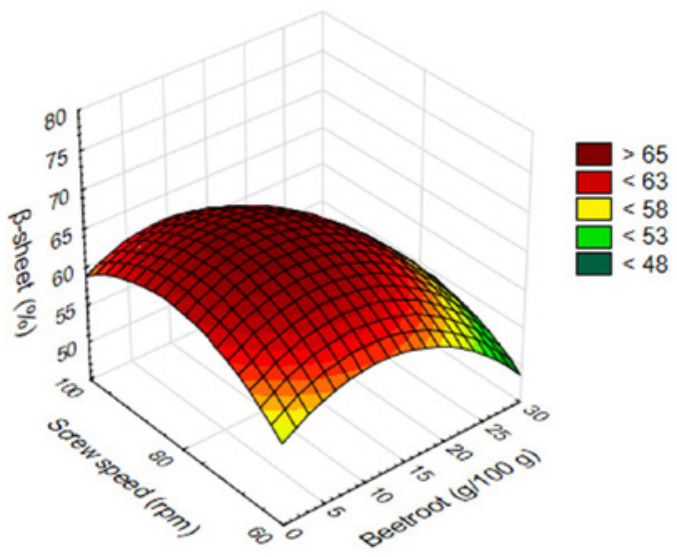

c)

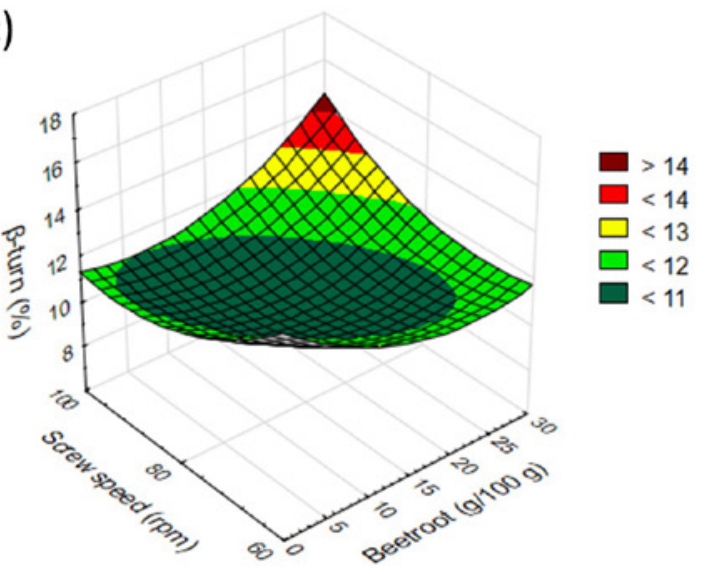

e)

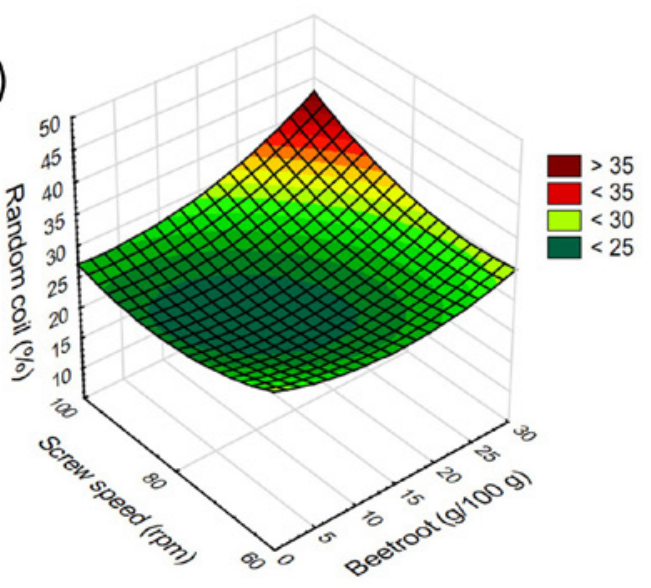

b)
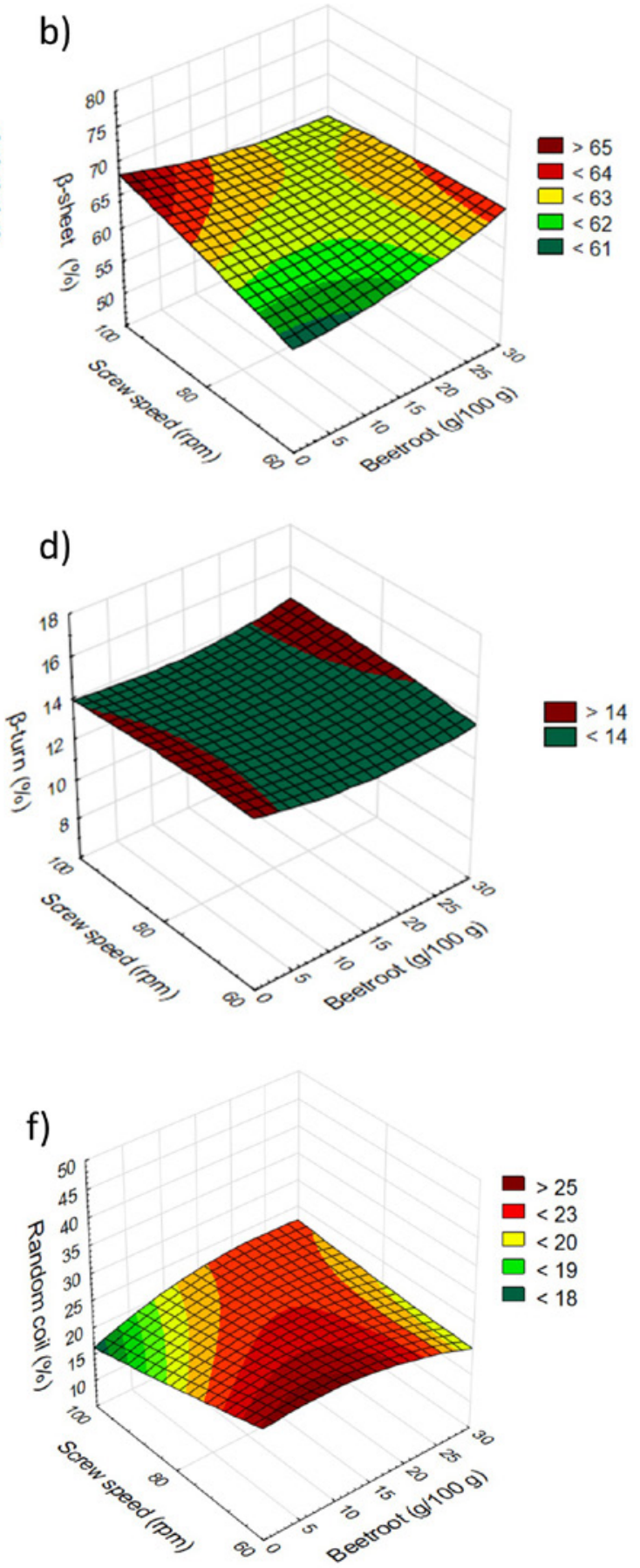

FIGURE 3. Processing variables dependence of relative composition of protein secondary structures calculated on the basis of deconvolution of FTIR spectra in the amide I region: a) $\beta$-sheet content of pellets, (b) $\beta$-sheet content of snacks, (c) $\beta$-turn content of pellets, (d) $\beta$-turn content of snacks, (e) random coil content of pellets, (f) random coil content of snacks. 
process, which caused the disappearance of the $\alpha$-helix structure. At this point, the extrusion process induced an ordering of the protein molecular structure. It should, however, be noted that strong interactions between neighboring $\alpha$-helices can also produce an increase in the absorption region characteristic of the $\beta$-sheet structure.

The formed pellets contained between 8.2 and $16.4 \%$ of $\beta$-turn, and no $\alpha$-helix (apart from above-mentioned sample), between 46.7 and $75.1 \%$ of $\beta$-sheet, as well as between 16.8 and $37.7 \%$ of random coil protein structures. Interestingly, the highest content of $\beta$-sheet was determined for the samples characterized by a relatively high beetroot pulp content $(7.5$ and $10.0 \mathrm{~g} / 100 \mathrm{~g})$ processed at all the applied screw speeds. This was accompanied by the highest $\beta$-sheet content (between 27.4\% (60 rpm), 37.7\% (80 rpm) and 35.9\% $(100 \mathrm{rpm}))$. Generally, an increase in the content of $\beta$-turn and $\beta$-sheet protein fractions was observed at the expense of random coil structure, indicating that the protein structure underwent some form of ordering as the molecular interactions in the proteins intensified. Therefore, the addition of fresh beetroot pulp resulted in an increase in the $\beta$-sheet structure content (the most stable protein structure). The pellets produced at the screw speed of $80 \mathrm{rpm}$ had the highest content of $\beta$-sheet structure (from $46.7 \%$ to $75.5 \%$ in the control, and $61.5 \%$ on average in the pellets containing beetroot pulp) as compared to $60 \mathrm{rpm}$ (from $47.5 \%$ in the control to $68.4 \%$ in the sample containing $7.5 \mathrm{~g} / 100 \mathrm{~g}$ of fresh beetroot pulp; $58.2 \%$ on average in the pellets with beetroot pulp), and $100 \mathrm{rpm}$ (from $50.5 \%$ in the control to $73.3 \%$ in the sample containing $10.0 \mathrm{~g} / 100 \mathrm{~g}$ of fresh beetroot pulp; $58.5 \%$ on average in the pellets with beetroot pulp). Interestingly, the pellets containing between 5.0 and $10.0 \mathrm{~g} / 100 \mathrm{~g}$ of fresh beetroot pulp had the highest fraction of this structure.

Our research indicated that the snacks contained less random coil protein structure and a little bit more of $\beta$-turn and $\beta$-sheet structure proteins, as compared to the not expanded pellets. This outcome points to the additional restructurization of the protein backbone. The microwave-expanded snacks contained between $12.6 \%$ and $14.4 \%$ of $\beta$-turn proteins, no $\alpha$-helix structures, as well as between $49.8 \%$ and $67.7 \%$ of $\beta$-sheet and between 18.7 and $36.7 \%$ of random coil structure proteins. The ranges of the fractions representing protein structures of the snacks were also narrower. This result additionally indicates that microwave radiation resulted in greater protein stabilization. Although from the statistical point of view it was not relevant, the highest fraction of $\beta$-structures was found for $80 \mathrm{rpm}$ of all the tested samples. The highest fraction of $\beta$-structures reached $66.8 \%$ for the snack containing $7.5 \mathrm{~g} / 100 \mathrm{~g}$ of beetroot pulp. Simultaneously, the smallest fraction of random coil was observed for the above-mentioned screw speed. Such a result may be due to a relatively long time of production/extrusion in the case of $60 \mathrm{rpm}$ and an increased temperature of the extrusion process in the case of $100 \mathrm{rpm}$ screw speed.

Finally, the highest fraction of $\beta$-structures and the smallest content of random coil structure were determined when $80 \mathrm{rpm}$ was applied during processing, which proves it to be the most efficient screw speed in the processing of fresh beetroot supplemented-snack pellets. Hence, these samples were subjected to the chemical composition analysis to evaluate the nutritional properties of snacks supplemented with fresh beetroot pulp.

\section{Analysis of starch conformation}

FTIR spectra in the region between 945 and $1195 \mathrm{~cm}^{-1} \mathrm{can}$ be used to obtain information about starch structure [Meziani et al., 2011]. This part of the spectra represents $\mathrm{COH}$ bending and $\mathrm{CH}_{2}$ related modes $\left(1077,1047,1022\right.$, and $\left.994 \mathrm{~cm}^{-1}\right)$ as well as $\mathrm{CO}$ and $\mathrm{C}-\mathrm{C}$ stretching modes $\left(1150 \mathrm{~cm}^{-1}\right)$. In addition, a peak at $994 \mathrm{~cm}^{-1}$ is sensitive to water content and starch conformation [van Soest et al., 1995].

The absorbance intensity ratio $(\mathrm{R})$ equal to I $\left(1047 \mathrm{~cm}^{-1}\right) /$ I $\left(1022 \mathrm{~cm}^{-1}\right)$ is frequently used as an indicator of the organization of different types of starch components [Hernández-Uribe et al., 2010; Meziani et al., 2011; Smits et al., 1998]. A high value of this ratio shows preponderance of the crystalline conformation over the amorphous conformation. This in turn indicates that starch has a strong tendency for retrogradation [Smits et al., 1998]. Additionally, in the region of $950-1200 \mathrm{~cm}^{-1}$ of FTIR spectra, starch shows sensitivity to the polymer conformation and hydration [Błaszczak et al., 2005]. In addition, the crystalline and amorphous zones of the starch are characterized by bands at $1047 \mathrm{~cm}^{-1}$ and $1022 \mathrm{~cm}^{-1}$, respectively [Hernández-Uribe et al., 2010].

The absorbance intensity ratio $(\mathrm{R})$ of the pellets and expanded snacks supplemented with fresh beetroot pulp is presented in Figure 4a and 4b, respectively. As indicated, the R value for the control blend before the extrusion-cooking was 0.68 . In the case of pellets, the minimum value of $\mathrm{R}(0.64)$ was noted for the samples with $30.0 \mathrm{~g} / 100 \mathrm{~g}$ of fresh beetroot pulp in the recipe when extruded at $100 \mathrm{rpm}$. In contrast, the maximum value $(0.71)$ was determined for half-products with $10.0 \mathrm{~g} / 100 \mathrm{~g}$ of vegetable additive processed at the screw speed of $80 \mathrm{rpm}$. After microwave treatment, the $\mathrm{R}$ value of the snacks decreased when compared to the results before expansion. The range of its values for the expanded snacks was from 0.60 (the samples with $7.5 \mathrm{~g} / 100 \mathrm{~g}$ of beetroot processed at $60 \mathrm{rpm}$ ) to 0.65 (the control expanded snack extruded at the screw speed of $80 \mathrm{rpm}$ ).

In analyzing gluten-free cake, Fetouhi et al. [2019] obtained the R-ratio between 0.6 and 0.8 and concluded that its high values indicated a high tendency of starch for retrogradation [Fetouhi et al., 2019].

Analysis of the absorbance intensity ratio (R) shows a strong starch retrogradation ability for pellets as compared to snacks, with the most pronounced effect demonstrated at the screw speed of $80 \mathrm{rpm}$. This might have been due to a relatively longer time of production/extrusion when a low screw speed was applied and to an increased temperature of the extrusion process if the $100 \mathrm{rpm}$ was used due to high friction and shear forces. On the other hand, starch of snacks showed much lesser tendency for retrogradation, which was the most visible at the screw speed of $60 \mathrm{rpm}$.

\section{Chemical composition}

Based on the results of physical, textural, and structural characteristics, the extruded pellets and microwave-expanded snacks processed at $80 \mathrm{rpm}$ - chosen as the optimum 
screw speed - were tested for their chemical composition. The control blend of potato components before extrusion had a protein content of $4.72 \pm 0.22 \mathrm{~g} / 100 \mathrm{~g}$, a fat content of $0.17 \pm 0.02 \mathrm{~g} / 100 \mathrm{~g}$, an ash content of $1.87 \pm 0.02 \mathrm{~g} / 100 \mathrm{~g}$, an insoluble dietary fiber content of $2.19 \pm 0.14 \mathrm{~g} / 100 \mathrm{~g}$, a soluble dietary fiber content of $3.75 \pm 0.15 \mathrm{~g} / 100 \mathrm{~g}$, and the total dietary fiber content at $5.94 \pm 0.16 \mathrm{~g} / 100 \mathrm{~g}$. The chemical composition of the pellets and expanded snacks supplemented with fresh beetroot pulp processed at $80 \mathrm{rpm}$ is presented in Table 3.

In the extruded pellets, supplementation with the fresh beetroot pulp up to $10.0 \mathrm{~g} / 100 \mathrm{~g}$ resulted in a lower protein content as compared to the control blend before extrusion. However, no significant $(\mathrm{p} \geq 0.05)$ differences were observed in the protein content of the extruded pellets supplemented with $0-10.0 \mathrm{~g} / 100 \mathrm{~g}$ of the pulp. When the fresh beetroot pulp was used at 20.0 and $30.0 \mathrm{~g} / 100 \mathrm{~g}$, the protein content was significantly $(\mathrm{p}<0.05)$ higher (Table 3$)$. Based on the PCA of the samples extruded at $80 \mathrm{rpm}$ screw speed (Figure $5 \mathrm{a}$ ), a negative correlation was found between the protein content and the fat content (vectors' position on opposite sides of the layout and $\alpha$-angle $<90^{\circ}$ ) in the pellets with Pearsons' coefficient at $\mathrm{r}=-0.57$, while a positive correlation was noticed between the protein content and contents of the remaining components of the chemical composition (vectors' position on the same side of the layout), with the correlation coefficient indicating a strong relation between protein content and ash contents $(r=0.98)$.

Among the snacks expanded by the microwave treatment, there was an increase in protein content with the increasing addition of fresh beetroot pulp. However, a significant $(\mathrm{p}<0.05)$ difference as compared to the control sample was determined only at 20.0 and $30.0 \mathrm{~g} / 100 \mathrm{~g}$ of fortification level. The PCA (Figure 5c) results showed a negative correlation between the protein content in the expanded snacks and the fat content and insoluble dietary fiber content due to the positions of vectors for these features, as confirmed also by Persons' coefficients $(r=-0.53$ and $r=-0.83$, respectively). Similarly to pellets, a positive correlation was shown between the protein content and ash $(\mathrm{r}=0.97)$ and soluble dietary fiber $(r=0.83)$ contents of the microwaved snacks. No significant effects of the extrusion-cooking processing variables or the addition of beetroot pulp on the fat content of the pellets were noticed. However, a negative correlation was found between the fat content and the soluble dietary fiber $(r=-0.80)$ and the total dietary fiber $(r=-0.60)$ contents in the pellets. In starch-rich extrudates in general, proteins act as diluents and reduce expansion due to their ability to affect water distribution in the matrix, and also because their macromolecular structure and conformation affect the rheological properties of extruded blends. Proteins also contribute to the formation of extensive networking through covalent links and electrostatic interactions that take place during the extrusion-cooking [Aguilar-Palazuelos et al., 2012]. This explains the negative correlation demonstrated between VEI and protein content in our study.

The microwave-expanded snacks with the addition of a minimum of $5.0 \%$ fresh beetroot pulp contained significantly $(\mathrm{p}<0.05)$ less fat than the control snacks. Additionally, there was a significant correlation between contents of both fiber fractions and the fat content in RTE snacks. The character of correlation was positive for the insoluble dietary fiber $(r=0.59)$ and negative for the soluble dietary fiber $(r=-0.57)$. The lower fat content in the expanded snacks could be due to the formation of protein-starch-fat complexes during thermal treatment both under extrusion-cooking and microwave conditions. Therefore, it may be concluded that every thermal treatment can successfully reduce fat content to produce low-fat snacks. Ruiz-Armenta et al. [2019] found a similar tendency for lowering fat content in both pellets and microwave-expanded snacks, and the differences they observed were significant (e.g., 1.50-2.47\% for unprocessed material, $0.28-1.10 \%$ for pellets, and $0.26-0.46 \%$ for RTE product). In turn, Lisiecka \& Wójtowicz [2021] found a much higher fat content in fried snacks supplemented with beetroot pulp, ranging from 22.27 to $30.76 \mathrm{~g} / 100 \mathrm{~g}$, and concluded that fresh beetroot inclusion up to $30.0 \mathrm{~g} / 100 \mathrm{~g}$ only slightly affected the fat content in the final puffs. Using the microwave treatment to expand snack pellets allowed achieving low-fat snacks, which is a nutritionally beneficial way to limit fat intake in the human diet. a)

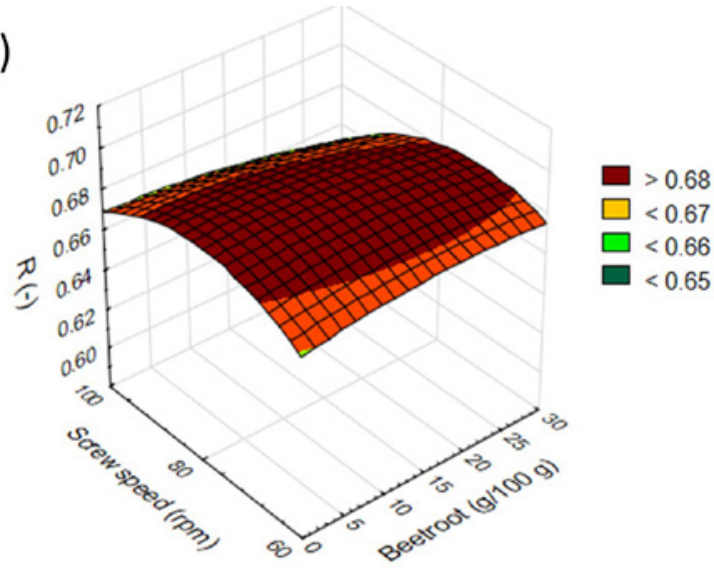

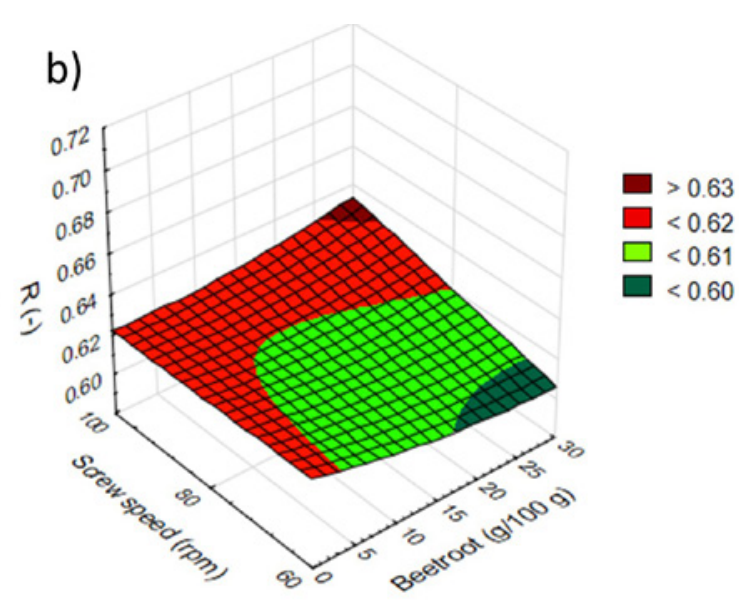

FIGURE 4. Absorbance intensity ratio R (-) of extruded pellets (a) and microwave-expanded snacks (b) supplemented with fresh beetroot pulp and processed at various screw speeds. 


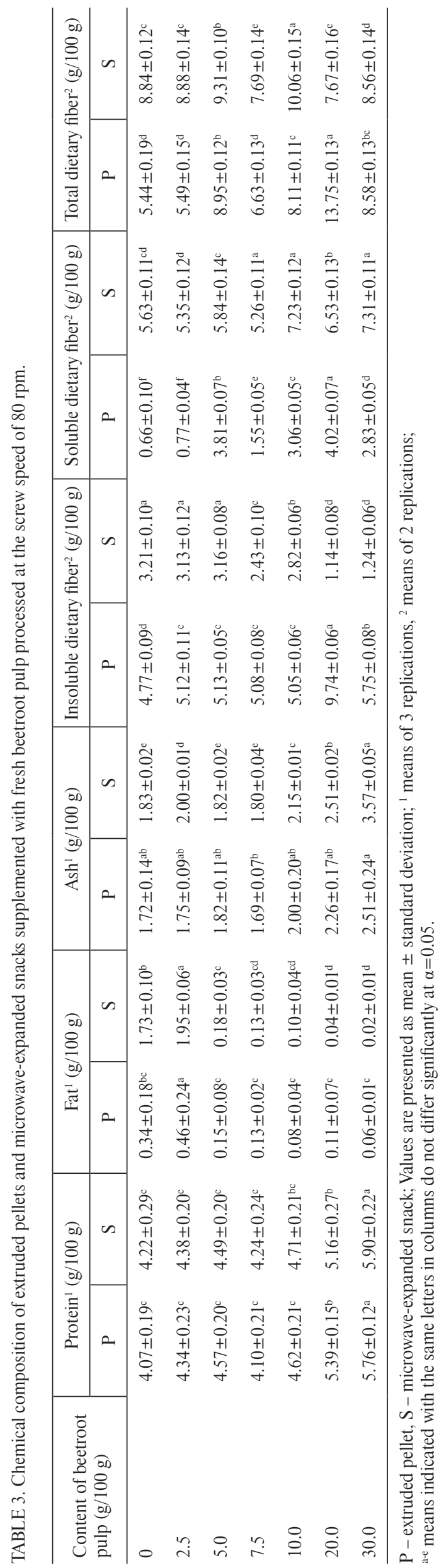

Pellets and snacks were, in general, characterized by a low ash content, while the maximum content of beetroot pulp in the recipe caused the highest ash content for both pellets and snacks (Table 3). The ash content of the pellets was positively correlated with the content of insoluble, soluble, and total dietary fiber contents, as shown by positions of vectors in Figure 5a, and as confirmed by Pearsons' coefficients ( $\mathrm{r}=0.54,0.58$, and 0.63 , respectively). In the case of microwave-expanded snacks, the ash content negatively correlated with the insoluble dietary fiber content $(\mathrm{r}=-0.80)$, and positively with the soluble dietary fiber content $(\mathrm{r}=0.75)$. The extrudates had significantly more insoluble dietary fiber compared to the control blend before extrusion (Table 3). However, the microwave treatment brought about a decrease in the insoluble dietary fiber and an increase in the soluble dietary fiber contents in the expanded snacks as compared to the pellets.

A positive correlation was found in the pellets between the insoluble dietary fiber content and the soluble $(r=0.56)$ and total dietary fiber fractions $(\mathrm{r}=0.90)$. A strong correlation between soluble and total dietary fiber contents in the pellets $(r=0.86)$ was noticed as well. In the case of the expanded snacks (Figure $5 \mathrm{c}$ ), a negative correlation was noted between the insoluble and the soluble dietary fiber fractions $(\mathrm{r}=-0.57)$, whereas a positive correlation was found between the insoluble and the total dietary fiber fractions $(r=0.53)$. The total fiber content in the pellets ranged from $5.44 \mathrm{~g} / 100 \mathrm{~g}$ (control sample), to $13.75 \mathrm{~g} / 100 \mathrm{~g}$ (the pellets with $20.0 \mathrm{~g} / 100 \mathrm{~g}$ addition of fresh beetroot pulp) (Table 3), while in the blend before extrusion, it was at $5.94 \mathrm{~g} / 100 \mathrm{~g}$. In the microwave-expanded snacks, the total fiber content ranged from $7.67 \mathrm{~g} / 100 \mathrm{~g}$ (the expanded snacks with $20.0 \mathrm{~g} / 100 \mathrm{~g}$ addition of fresh beetroot pulp) to $10.06 \mathrm{~g} / 100 \mathrm{~g}$ (the expanded snacks with $10.0 \mathrm{~g} / 100 \mathrm{~g}$ addition of fresh beetroot pulp). Probably, due to the high amount of fiber-rich beetroot pulp, the samples with its $30 \mathrm{~g} / 100 \mathrm{~g}$ content underwent lesser transformation during extrusion. After microwave expansion, the structure of snacks with a higher pulp content was different than that of the snacks with $20 \mathrm{~g} / 100 \mathrm{~g}$ of the pulp content, which was also confirmed by the FTIR analysis, especially when looking at starch transformation after microwaving. During the extrusion-cooking, fibrous fractions of beetroot may disrupt the formation of starch and protein complexes, which could also affect contents of soluble and insoluble dietary fiber. Generally, the content of soluble dietary fiber increases after extrusion. It may be the effect of microwave treatment that is changing material structure, as confirmed by differences in FTIR spectra of pellets and expanded snacks. Moreover, it was found that VEI decreased with an increasing content of soluble dietary fiber in the extrudates. Delgado-Nieblas et al. [2012] concluded that a decrease in VEI could result from the high content of dietary fiber in winter squash, because fiber can make the cell walls collapse during the formation of steam bubbles, reducing the ability to retain air inside the formed cells and therefore reducing expansion. Ruiz-Armenta et al. [2019] reported lower crude fiber contents in pellets and microwave-expanded snacks, ranging from 0.94 to $1.94 \%$ for unprocessed material based on blends of corn starch/whole yellow corn flour with naranjita bagasse 
and/or skimmed milk powder, through 0.83 to $1.88 \%$ for pellets, and to 0.78 to $1.75 \%$ for expanded products depending on the recipe variant. The high dietary fiber content of the snacks supplemented with fresh beetroot pulp means that they could be labelled as "high fiber products" according to the European Regulation (more than $6 \mathrm{~g} / 100 \mathrm{~g}$ of fiber) [Regulation (EC) No 1924/2006, 2006].

\section{PCA results}

Figures $5 \mathrm{a}$ and $5 \mathrm{c}$ present variables for pellets and snacks, respectively (position of the load vectors in relation to the first two principal components). The distance and location of the studied properties between each other indicates the type of correlation between features (positive or negative - depending on the position of vector in an adequate square on graph and $\alpha$-angle value). The position of vectors at the same part of the layout and an $\alpha$-angle below $90^{\circ}$ indicate a positive correlation, whereas opposite location of vectors indicate a negative correlation. In addition, together with the PCA, a correlation matrix was generated between the tested features showing the exact Pearsons' correlation coefficients cited in the manuscript. Approximately $74 \%$ of all the variance in the pellets data was explained by the first two principal components, PC1 (54.58\%) and PC2 (19.14\%). PC1 was strongly positively correlated with $\beta$-sheet protein and fat contents and strongly negatively correlated with random coil structure content, as well as with other components of chemical composition. In addition, PC2 was strongly positively correlated with R (Figure 5a). After placing the samples
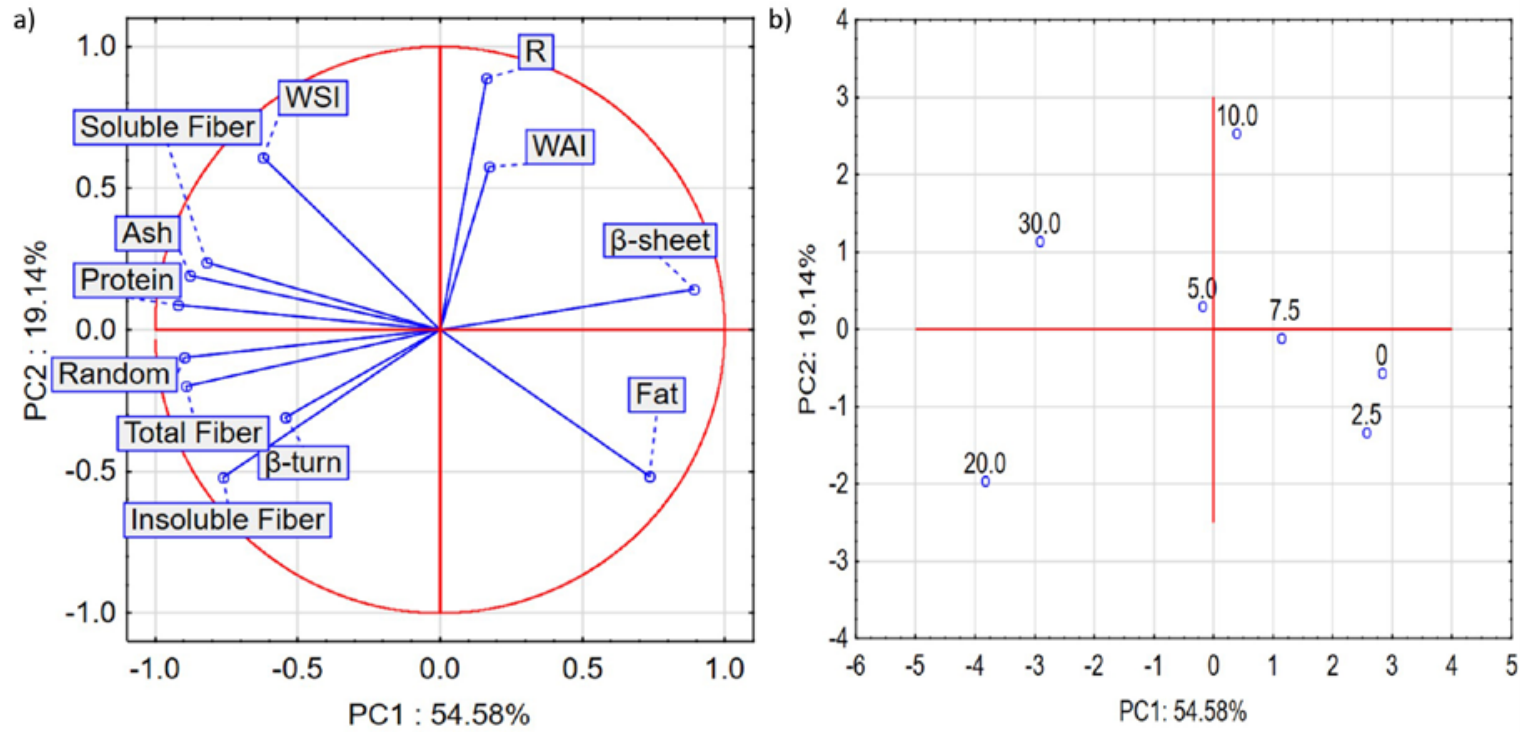

c)

d)
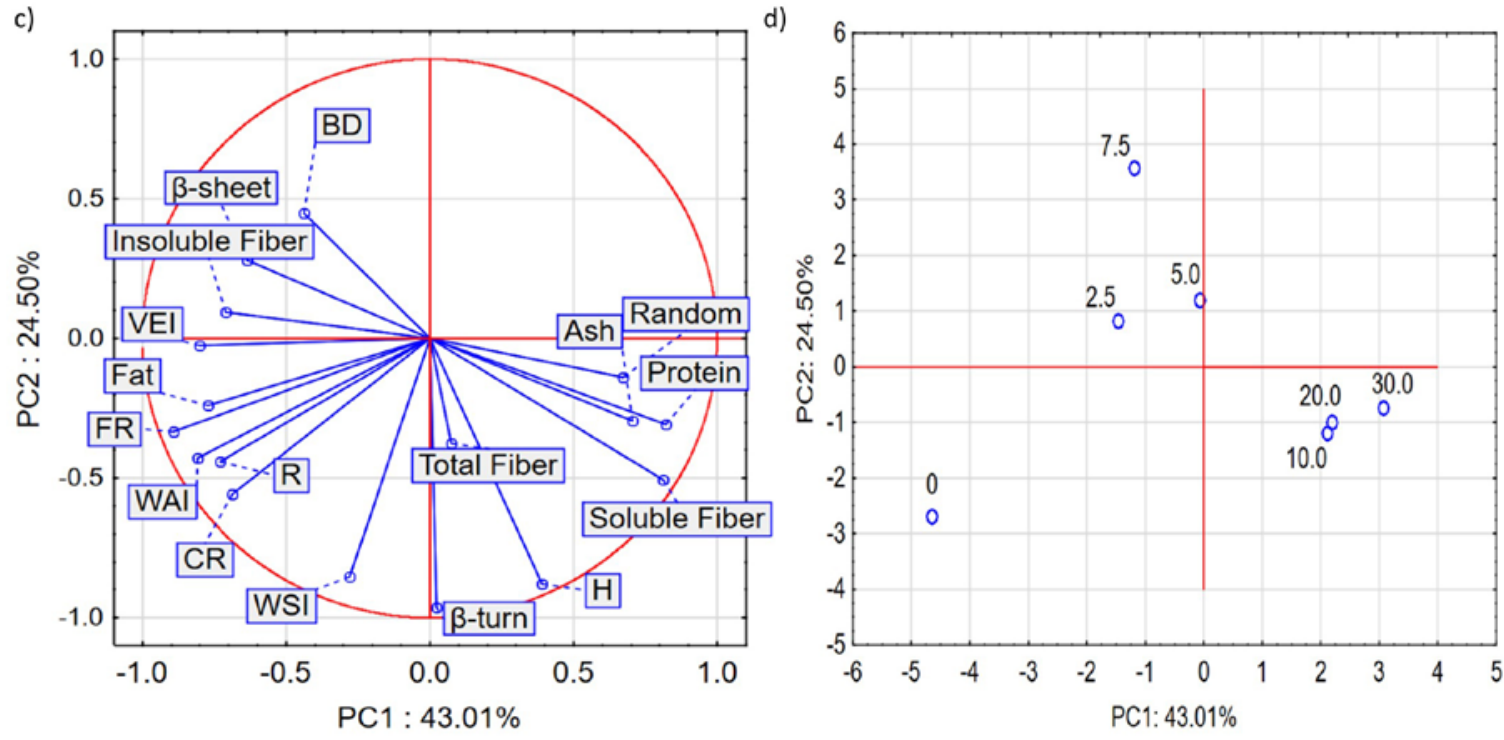

FIGURE 5. Principal component analysis (PCA) of extruded pellets (a) and expanded snacks (b) processed at 80 rpm, as well as objects characteristics of pellets (c) and snacks (d) in the space of the first two principal components (PC1 and PC2); 0-30.0 - content of fresh beetroot pulp (g/100 g). WAI - water absorption index; WSI - water solubility index; BD - bulk density; VEI - volumetric expansion index; H - hardness; CR - crispness; FR - fracturability; $\beta$-sheet - $\beta$-sheet content; $\beta$-turn - $\beta$-turn content; Random - random coil structure; $\mathrm{R}$ - absorbance intensity ratio; Protein - protein content; Fat - fat content; Ash - ash content; Insoluble fiber - insoluble dietary fiber content; Soluble fiber - soluble dietary fiber content; Total fiber - total dietary fiber content. 
in the space of the first two components (Figure 5b), they differed from each other depending on beetroot pulp content. Significant differences can be observed between the pellets with $20.0 \mathrm{~g} / 100 \mathrm{~g}$ and higher fresh beetroot pulp contents and those with lower pulp contents. From this plot, it can be concluded that the first principal component describes the system variability and determines the level of the additive in the pellets. In turn, in RTE snacks analysis, the first principal component (PC1) explained $43.01 \%$ of the total variance in the results and was strongly positively correlated with protein, ash, and soluble fiber contents as well as with random coil values, and negatively with WAI, fat content, insoluble fiber content, $\mathrm{R}$ ratio values, expansion index, and fracturability. What is more, the second principal component (PC2) explained $24.50 \%$ of the total variance of the results and was strongly negatively correlated with $\beta$-turn protein content, WSI, and hardness (Figure 5c). Placing the supplemented expanded snacks in the space of the examined principal component (Figure 5d) showed, in general, increasing differences between the samples as the fresh beetroot pulp amount increased, while some similarity was observed for the samples with the beetroot pulp content ranging from 10.0 to $30.0 \mathrm{~g} / 100 \mathrm{~g}$. From this graph, it can be concluded that the first principal component describes the system variability and determines the parameter of the fresh beetroot pulp content in the microwave-expanded snacks.

When assessing correlations of chemical composition and physical properties of the pellets and snacks by the PCA, it was shown that WAI of the pellets was negatively correlated (Figure 5a) with the content of soluble fiber, with a correlation coefficient at $r=-0.60$. In our research, a negative correlation was noticed between the WAI value and protein content $(r=-0.60)$, soluble dietary fiber content $(r=-0.52)$, and ash content $(\mathrm{r}=-0.55)$ of the snacks. In turn, a positive correlation (Figure $5 \mathrm{c}$ ) was noticed between the WAI and fat content $(r=0.79)$, insoluble dietary fiber content $(r=0.66)$, and WSI $(r=0.62)$ of the snacks. Additionally, PCA and correlation coefficients calculated showed the WSI of pellets was positively correlated (Figure $5 \mathrm{a}$ ) with their contents of protein $(\mathrm{r}=0.65)$, ash $(r=0.67)$, soluble dietary fiber $(r=0.73)$, and the total dietary fiber $(r=0.56)$, and negatively correlated with their fat content $(r=-0.67)$. Our work confirmed the change in the crystallization of starch after processing of both extruded and microwaved samples as compared to native starch granules (Figure $5 \mathrm{a}$ and $5 \mathrm{c}$, respectively).

PCA and correlation coefficients calculated for the snacks showed that their bulk density was negatively correlated (Figure 5c) with their content of random coil protein fraction $(r=-0.87)$, and positively correlated with $\beta$-sheet protein fraction $(\mathrm{r}=0.93)$. While VEI was positively correlated with WAI $(r=0.68)$, fat content $(r=0.76)$, insoluble dietary fiber content $(r=0.70)$, and fracturability $(r=0.80)$. Additionally, VEI was negatively correlated with contents of protein $(\mathrm{r}=-0.86)$, ash $(\mathrm{r}=-0.80)$ and soluble dietary fiber $(\mathrm{r}=-0.69)$. Hardness was only positively correlated with $\beta$-turn protein fraction $(r=0.80)$, WSI $(r=0.67)$, protein content $(r=0.64)$, ash content $(r=0.60)$, and soluble dietary fiber content $(r=0.70)$. Crispness was positively correlated with R-ratio of starch $(r=0.96)$, WAI $(r=0.66)$, WSI $(r=0.72)$, and fracturability $(\mathrm{r}=0.84)$, and negatively correlated with random coil structure content $(r=-0.63)$. Fracturability was negatively correlated with protein content $(\mathrm{r}=-0.62)$ and positively correlated with R-ratio of starch $(r=0.76)$, WAI $(0.77)$, fat content $(r=0.82)$, and insoluble dietary fiber content $(r=0.59)$.

The structure analysis of pellets and expanded snacks made by FTIR was also analyzed by PCA as the function of two main variables and correlation coefficients calculated, and was connected with the chemical composition as well as physical properties of the tested samples. We noted that the $\beta$-sheet content of pellet proteins was negatively correlated with $\beta$-turn $(\mathrm{r}=-0.71)$, random coil $(\mathrm{r}=-0.98)$ protein structure, the total protein content $(\mathrm{r}=-0.80)$, ash $(\mathrm{r}=-0.76)$, insoluble, soluble and total dietary fiber $(r=-0.62, r=-0.60$, and $r=-0.69$, respectively), while positively correlated with fat content (with $\mathrm{r}=0.64$ ) in semi-products (Figure 5a). The $\beta$-sheet of microwave-expanded snack proteins was only negatively correlated (Figure $5 \mathrm{c}$ ) with the random coil structure, with Pearsons' correlation coefficients expressed as $r=-0.98$ and with soluble dietary fiber content $(r=-0.60)$, and positively correlated with bulk density $(r=0.92)$ and crispness $(r=0.52)$. Moreover, the pellet protein $\beta$-turn fraction was positively correlated with random coil structure $(r=0.57)$, protein content $(\mathrm{r}=0.72)$, and content of insoluble dietary fiber $(r=0.69)$, while the $\beta$-turn protein fraction of the microwaved snacks was positively correlated with WSI $(r=0.72)$ and soluble dietary fiber content $(r=0.52)$, hardness $(r=0.80)$ and crispness $(\mathrm{r}=0.54)$ of snacks, and negatively correlated with $\mathrm{BD}(\mathrm{r}=-0.59)$. The pellet protein random coil structure was correlated with all chemical components, but the strongest correlation was found between random coil structure and protein $(r=0.75)$ and total dietary fiber $(r=0.75)$ contents. In the case of expanded snacks supplemented with fresh beetroot pulp, random coil structure was positively correlated only with soluble dietary fiber content $(r=0.52)$ and negatively with BD $(r=-0.87)$, crispness $(r=-0.63)$ and fracturability ( $r=-0.58)$. In turn, the $\mathrm{R}$ ratio of pellets was positively correlated with WSI $(r=0.54)$ and negatively correlated with insoluble dietary fiber content $(r=-0.58)$. Moreover, the $\mathrm{R}$ of the microwave-expanded snacks was positively correlated with WAI $(r=0.70)$, WSI $(r=0.68), \beta$-sheet protein fraction $(r=0.55)$, crispness $(r=0.96)$, and fracturability $(r=0.76)$, but negatively with random coil structure content $(r=-0.64)$.

Hence, the application of PCA provided an overall view of the correlations between all the tested features of newly developed pellets and snacks supplemented with fresh beetroot pulp and identified the main components important in quality analysis of extruded pallets and microwave-expanded low-fat snacks.

\section{CONCLUSIONS}

Selected physical properties as well as texture and structure parameters were analyzed for both extruded snack pellets and microwave-expanded snacks. The use of fresh beetroot pulp in RTE snacks caused a reduction in their volumetric expansion due to increased contents of dietary fiber and protein instead of starch. The addition of vegetable pulp also resulted in the stabilization of the protein backbone structure, which was expressed by a decrease in random coil structure and an increase in $\beta$-turn protein fraction. Interestingly, the ranges 
of the fractions representing protein structures in the snacks were narrower than those observed for the pellets by FTIR analysis. This indicates that microwave treatment also resulted in greater protein stabilization. The highest content of $\beta$-structure protein fraction and the smallest content of random coil was observed if $80 \mathrm{rpm}$ screw speed was applied during pellet processing. In the microwave-expanded snacks supplemented with beetroot, an increase in the fresh vegetable pulp addition raised the protein content. Moreover, the addition of $5.0 \mathrm{~g} / 100 \mathrm{~g}$ and more of fresh beetroot pulp as a starch substitute significantly reduced the fat content in the snacks compared to the potato control sample. We found that the extrusion-cooking caused an increase in the insoluble dietary fiber content and WAI in the obtained pellets, but the microwave treatment reduced the value of this parameter and increased insoluble dietary fiber content in the final RTE snacks compared to the semi-products. The highest fraction of $\beta$-structures and the smallest content of random coil were observed when $80 \mathrm{rpm}$ was applied during processing, suggesting this screw speed to be the most efficient in processing fresh beetroot pulp-supplemented snack pellets. The use of a fresh beetroot pulp as an additive in microwave-expanded snacks made it possible to obtain products with an increased amount of fiber and a reduced fat content as an attractive and healthy alternative to deep-fried snacks. Moreover, application of fresh beetroot in extruded products allows minimizing the technological water and energy consumption due to the omission of beetroot drying step.

\section{RESEARCH FUNDING}

This research did not receive any specific grant from funding agencies in the public, commercial, or not-for-profit sectors.

\section{CONFLICT OF INTERESTS}

Authors declare no conflict of interest.

\section{ORCID IDs}

K. Lisiecka https://orcid.org/0000-0003-0659-8704

A. Sujak https://orcid.org/0000-0001-5616-3827

A. Wójtowicz https://orcid.org/0000-0001-5981-6109

\section{REFERENCES}

1. AACC. (1995). Approved Methods of the American Association of Cereal Chemists (9th ed.). St. Paul, USA.

2. Aguilar-Palazuelos, E., Zazueta-Morales, J., Harumi, E.N., Martínez-Bustos, F. (2012). Optimization of extrusion process for production of nutritious pellets. Food Science and Technology, 32(1), 34-42.

https://doi.org/10.1590/S0101-20612012005000005

3. Alvarez, M.D., Paniagua, J., Herranz, B. (2020). Assessment of the miniature Kramer Shear Cell to measure both solid food and bolus mechanical properties and their interplay with oral processing behavior. Foods, 9, art. no. 613 https://doi.org/10.3390/ foods9050613

4. AOAC. (2000). Official Methods of AOAC International (17th ed.). Gaithersburg, USA.
5. Bhat, N.S., Wani, I.A., Hamdani, A.M., Gani, A. (2019). Effect of extrusion on the physicochemical and antioxidant properties of value added snacks from whole wheat (Triticum aestivum $\mathrm{L}$.) flour. Food Chemistry, 276, 22-32.

https://doi.org/10.1016/j.foodchem.2018.09.170

6. Błaszczak, W., Valverde, S., Fornal, J. (2005). Effect of high pressure on the structure of potato starch. Carbohydrate Polymers, 59, 377-383.

https://doi.org/10.1016/j.carbpol.2004.10.008

7. Bock, J.E., Damodaran, S. (2013). Bran-induced changes in water structure and gluten conformation in model gluten dough studied by Fourier transform infrared spectroscopy. Food Hydrocolloids, 31, 146-155.

https://doi.org/10.1016/j.foodhyd.2012.10.014

8. Chen, F., Zhang, M., Mujumdar, A.S., Jiang, H., Wang, L. (2014). Production of crispy granules of fish: a comparative study of alternate drying techniques. Drying Technology, 32(12), 1512-1521. https://doi.org/10.1080/07373937.2014.903410

9. Delgado-Nieblas, C., Aguilar-Palazuelos, E., Gallegos-Infante, A., Rocha-Guzmán, N., Zazueta-Morales, J., Caro-Corrales, J. (2012). Characterization and optimization of extrusion cooking for the manufacture of third-generation snacks with winter squash (Cucurbita moschata D.) flour. Cereal Chemistry, 89, 65-72.

https://doi.org/10.1094/CCHEM-02-11-0016

10. Fetouhi, A., Benatallah, L., Nawrocka, A., Szymańska-Chargot, M., Bouasla, A., Tomczyńska-Mleko, M., Zidoune M.N., Sujak, A. (2019). Investigation of viscoelastic behaviour of rice-field bean gluten free dough using the biophysical characterization of proteins and starch: a FT-IR study. Journal of Food Science and Technology, 56(3), 1316-1327.

https://doi.org/10.1007/s13197-019-03602-2

11. Han, Y., Tran, T., Le, V. (2018). Corn snack with high fiber content: Effects of different fiber types on the product quality. LWT - Food Science and Technology, 96, 1-6.

https://doi.org/10.1016/j.lwt.2018.05.014

12. Hernández-Uribe, J.P., Ramos-López, G., Yee-Madeira, H., Bello-Pérez, L.A. (2010). Physicochemical, rheological and structural characteristics of starch in maize tortillas. Plant Foods for Human Nutrition, 65, 152-157.

https://doi.org/10.1007/s11130-010-0165-5

13. Kaur, G.J., Rehal, J., Singh, B., Singh, A.K., Kaur, A. (2015). Development of multigrain breakfast cereal using extrusion technology. Asian Journal of Dairy \& Food Research, 34(3), 219-224. https://doi.org/10.5958/0976-0563.2015.00043.3

14. Kowalczuk, D., Pitucha, M. (2019). Application of FTIR method for the assessment of immobilization of active substances in the matrix of biomedical materials. Materials (Basel), 12(18), art. no. 2972. https://doi.org/10.3390/ma12182972

15. Krishnaraj, P., Anukiruthika, T., Choudhary, P., Moses, J.A., Anandharamakrishnan, C. (2019). 3D extrusion printing and post-processing of fibre-rich snack from indigenous composite flour. Food and Bioprocess Technology, 12, 1776-1786. https://doi.org/10.1007/s11947-019-02336-5

16. Lisiecka, K., Wójtowicz, A. (2021). Effect of fresh beetroot application and processing conditions on some quality features of new type of potato-based snacks. LWT - Food Science and Technology, 141, art. no. 110919. https://doi.org/10.1016/j.lwt.2021.110919 
17. Lisiecka, K., Wójtowicz A. (2020). Possibility to save water and energy by application of fresh vegetables to produce supplemented potato-based snack pellets. Processes, 8(2), art. no. 153. https://doi.org/10.3390/pr8020153

18. Lisiecka, K., Wójtowicz, A. (2019). The influence of fresh kale addition on selected properties of corn snacks. International Journal of Food Engineering, 15(11-12), 1-11.

https://doi.org/10.1515/ijfe-2018-0319

19. Lisiecka, K., Wójtowicz, A., Mitrus, M., Oniszczuk, T., Combrzyński, M. (2021). New type of potato-based snack-pellets supplemented with fresh vegetables from the Allium genus and its selected properties. LWT - Food Science and Technology, 145, art. no. 111233 .

https://doi.org/10.1016/j.Iwt.2021.111233

20. Lourenço, L.F.H., Tavares, T.S., Araujo, E.A.F., Eder, A.F., Pena, R.S., Rosinelson, S., Peixoto Joele, M.R.G., Carvalho, A.V. (2016). Optimization of extrusion process to obtain shrimp snacks with rice grits and polished rice grains. CyTA: Journal of Food, 14(2), 340-348.

https://doi.org/10.1080/19476337.2015.1114025

21. Meziani, S., Jasniewski, J., Gaiani, C., Ioannou, I., Muller, J.M., Ghoul, M., Desobry, S. (2011). Effects of freezing treatments on viscoelastic and structural behavior of frozen sweet dough. Journal of Food Engineering, 107, 358-365.

https://doi.org/10.1016/j.jfoodeng.2011.07.003

22. Mikołajczyk-Bator, K., Błaszczyk, A., Czyżniejewski, M., Kachlicki, P. (2016). Characterisation and identification of triterpene saponins in the roots of red beets (Beta vulgaris L.) using two HPLC-MS systems. Food Chemistry, 1(192), 979-90.

https://doi.org/10.1016/j.foodchem.2015.07.111

23. Pytlak, A., Szafranek-Nakonieczna A., Sujak, A., Grządziel, J., Polakowski, C., Kuźniar, A., Proc, A., Kubaczyński, A., Goraj, W., Gałązka, A., Gruszecki, W.I., Bieganowski, A., Stępniewska, Z. (2020). Stimulation of methanogenesis in bituminous coal from the upper Silesian coal basin. International Journal of Coal Geology, 231(1), art. no. 103609.

https://doi.org/10.1016/j.coal.2020.103609

24. Rashid, S., Rakha, A., Anjum, F., M., Ahmed, W., Sohail, M. (2015). Effects of extrusion cooking on the dietary fibre content and Water Solubility Index of wheat bran extrudates. Journal of Food Science and Technology, 50(7), 1533-1537.

https://doi.org/10.1111/ijfs.12798

25. Regulation (EC) No 1924/2006 of the European Parliament and of the Council of 20 December 2006 on nutrition and health claims made on foods. Official Journal of the European Union, OJ L 404, 30.12.2006.

https://eur-lex.europa.eu/eli/reg/2006/1924/2014-12-13

26. Ruiz-Armenta, X.A., Zazueta-Morales, J.D.J., Delgado-Nieblas, C.I., Carrillo-López, A., Aguilar-Palazuelos, E., Camacho-
-Hernández, I.L. (2019). Effect of the extrusion process and expansion by microwave heating on physicochemical, phytochemical, and antioxidant properties during the production of indirectly expanded snack foods. Journal of Food Processing and Preservation, 43(12), art. no. e14261.

https://doi.org/10.1111/jfpp.14261

27. Sakač, N., Karnaš, M., Dobša, J., Jozanović, M., Gvozdić V., Kovač-Andrić, E., KraševacSakač, M., Šarkanj, B. (2020). Application of spectrophotometric fingerprint in cluster analysis for starch origin determination. Food Technology \& Biotechnology, $58(1), 5-12$.

https://doi.org/10.17113/ftb.58.01.20.6239

28. Sanchez-González, J.A., Echeverria, C., Lescano, L., Linares, G., Arteaga-Miñano H.L., Soriano-Colchado, J., Barraza-Jáuregui, G. (2019). Physico-chemical, thermal and rheological characteristics of starch isolated from four commercial potatoes cultivars. Scientia Agropecuaria, 10(1), 63-71.

https://doi.org/10.17268/sci.agropecu.2019.01.07

29. Seabourn, B.W., Chung, O.K., Seib, P.A., Mathewson, P.R. (2008). Determination of secondary structural changes in gluten proteins during mixing using Fourier transform horizontal attenuated total reflectance spectroscopy. Journal of Agricultural and Food Chemistry, 56, 4236-4243.

https://doi.org/10.1021/jf703569b

30. Shah, F.U.H., Sharif, M.K., Butt, M.S., Shahid, M. (2017). Development of protein, dietary fiber, and micronutrient enriched extruded corn snacks. Journal of Texture Studies, 48, 221-230.

https://doi.org/10.1111/jtxs.1223

31. Sharma, S., Singh, N., Singh, B. (2015). Effect of extrusion on morphology, structural, functional properties and in vitro digestibility of corn, field pea and kidney bean starches. Starch/Stärke, 67, 721-728.

https://doi.org/10.1002/star.201500021

32. Smits, A.L.M., Ruhnau, F.C., Vliegenthart J.F.G., van Soest, U.F.G., van Soest, J.J.G. (1998). Ageing of starch based systems as observed with FT-IR and solid state NMR spectroscopy. Starch/Stärke, 50, 478-483.

https://doi.org/10.1002/(SICI)1521-379X(199812)50:11/12<478:: AID-STAR478>3.0.CO;2-P

33. Susi, H., Byler, D.M. (1983). Protein structure by Fourier transform infrared spectroscopy: second derivative spectra. Biochemical and Biophysical Research Communications, 115, 391-397. https://doi.org/10.1016/0006-291X(83)91016-1

34. van Soest, J.J.G., Tourois, H., de Wit, D., Veliegenthart, J.F.G. (1995). Short-ranges structure in (partially) crystalline potato starch determined with attenuated total reflectance Fourier-transform IR spectroscopy. Carbohydrate Research, 279, 201-214. https://doi.org/10.1016/0008-6215(95)00270-7 